\title{
Vertical flux and fate of particulate matter in a Newfoundland fjord at sub-zero water temperatures during spring
}

\author{
R. J. Thompson ${ }^{1}$, D. Deibel ${ }^{1, *}$, A. M. Redden ${ }^{2}$, C. H. McKenzie ${ }^{3}$ \\ ${ }^{1}$ Ocean Sciences Centre, Memorial University, St. John's, Newfoundland and Labrador A1C 5S7, Canada \\ ${ }^{2}$ Acadia Centre for Estuarine Research, Acadia University, Wolfville, Nova Scotia B4P 2R6, Canada \\ ${ }^{3}$ Northwest Atlantic Fisheries Centre, Department of Fisheries and Oceans Canada, St. John's, \\ Newfoundland and Labrador A1C 5X1, Canada
}

\begin{abstract}
To test the hypothesis that low temperature inhibits utilization of sinking spring bloom material, we studied the formation and fate of the bloom in Conception Bay, Newfoundland, Canada, where the entire water column is $<0^{\circ} \mathrm{C}$ during the spring bloom and the benthos is $<-1^{\circ} \mathrm{C}$ year round. The bloom formed in April and sank from the upper mixed layer in May, following nutrient depletion in the upper $50 \mathrm{~m}$. Using sediment traps $(40,80,150$, and $240 \mathrm{~m}$ depth), we determined timeaveraged fluxes of total particulate matter, particulate organic carbon, particulate organic nitrogen, and chlorophyll $a$ as the material sank to the bottom. The sinking material was dominated by zooplankton fecal pellets before and after the sinking event, but by diatom vegetative cells and spores during it. Over half (56\%) of the primary production during the spring bloom was exported from the upper mixed layer. The principal fate of sinking phytodetritus was aerobic utilization by benthic microorganisms $(42 \%)$, followed by consumption by water column zooplankton $(18 \%)$. Although rates of primary production and sinking in Conception Bay were not exceptional in a global context, the quality of the sinking material was extremely high in terms of properties such as percent organic matter, percent carbon, and percent nitrogen. We found little evidence for low temperature regulation of the utilization of organic carbon from the spring bloom in Conception Bay, but we propose a role of low temperature in maintaining high nutritional quality of sinking phytodetritus.
\end{abstract}

KEY WORDS: Vertical flux $\cdot$ Sediment trap $\cdot$ Spring bloom $\cdot$ Pigments $\cdot$ Temperature $\cdot$ Benthos

Resale or republication not permitted without written consent of the publisher

\section{INTRODUCTION}

The sedimentation of spring phytoplankton is a common feature of temperate and polar coastal seas (Beaulieu 2002, Tian et al. 2003, Tamelander \& Heiskanen 2004). Although fecal pellets produced by herbivorous zooplankton are generally important in the vertical flux of phytogenous material (Bathmann et al. 1987), sedimentation of ungrazed phytoplankton during spring blooms is often quantitatively more important than fecal pellet flux (Smetacek 1985a, Andreassen \& Wassmann 1998), perhaps due to a relatively low biomass of overwintering herbivorous zooplankton, particularly in cold, northern waters (Smetacek 1985b, Ramos et al. 2003). Furthermore, a temporal lag in the numerical response of zooplankton populations to a short period of rapid phytoplankton growth may result in limited grazing impact during spring (Dagg et al. 1982, Parsons 1988). Consequently, a large portion of the phytoplankton biomass settles out of the euphotic zone in the form of intact cells, cysts, diatom chains, and flocs during the senescent stage of the bloom (Smetacek 1985a, Ramos et al. 2003, Tamelander \& Heiskanen 2004).

Sedimentation during spring blooms supplies significant amounts of organic matter and energy to suprabenthic, epibenthic, and benthic environments, directly linking phytoplankton production to food 
webs beneath the euphotic zone (Fabiano et al. 2001, Beaulieu 2002, Mincks et al. 2005). The spring pulse of sinking organic matter is often the principal energy source for these communities. In temperate and high latitudes, as much as half of the annual input of organic matter to the benthos is deposited during spring (Townsend \& Cammen 1988, Grebmeier \& McRoy 1989). The response to sinking phytodetritus is often rapid throughout the food web, from bacteria and protists to benthopelagic peracarid crustaceans and benthic bivalves (Pomeroy et al. 1991, Drazen et al. 1998, Glud et al. 1998, Stead \& Thompson 2003, Richoux et al. 2004a,b), although other studies have reported little response of the benthos to pulses of phytodetritus (Josefson et al. 2002, Mincks et al. 2005). In bays and fjords of temperate regions, zooplankton grazing may play an important role in the transport of organic carbon and may be the primary contributor to the vertical flux of phytoplankton production (Peinert et al. 1989, Juul-Pedersen et al. 2006).

Although Newfoundland fjords are located in midlatitudes, their oceanographic characteristics are typical of sub-arctic seas, owing to the influence of the Labrador Current (de Young \& Sanderson 1995). Given these conditions, which of the following patterns for utilization of the spring bloom should we expect in a Newfoundland fjord: close coupling, with high rates of bacterial and zooplankton utilization of sinking material in the water column, or weak coupling, resulting in high rates of organic matter flux to the benthos?

Conception Bay is located on the east coast of the island of Newfoundland, Canada, and is oriented roughly northeast to southwest, opening onto the inshore branch of the Labrador Current (Fig. 1). The fjord is approximately $25 \mathrm{~km}$ wide $\times 85 \mathrm{~km}$ long, with a maximum depth in the southwestern depositional basin of about $300 \mathrm{~m}$ and a sill at $150 \mathrm{~m}$. Pack ice may occur from mid-March to late April, depending on the concentration of ice offshore and the frequency and duration of onshore, northeasterly winds. Freshwater runoff is relatively insignificant within the bay compared to sea-ice melt upstream. Water temperatures are generally low in Conception Bay, which has a permanent cold intermediate layer (80 to $120 \mathrm{~m}$ depth) that remains $<0^{\circ} \mathrm{C}$ year round and a near-bottom water mass that never exceeds $-0.8^{\circ} \mathrm{C}$ (Pomeroy et al. 1991, deYoung \& Sanderson 1995), a fact that has been overlooked in the literature (e.g. Rysgaard et al. 1998). These low temperatures may have a profound effect on heterotrophic utilization of the products of primary production in the water column, both by bacteria (Pomeroy et al. 1991, Budge \& Parrish 2003, Mincks et al. 2005) and by zooplankton (Parsons 1988). However, Pomeroy et al. (1991) reported relatively high rates of carbon remineralization in the surficial sediments of

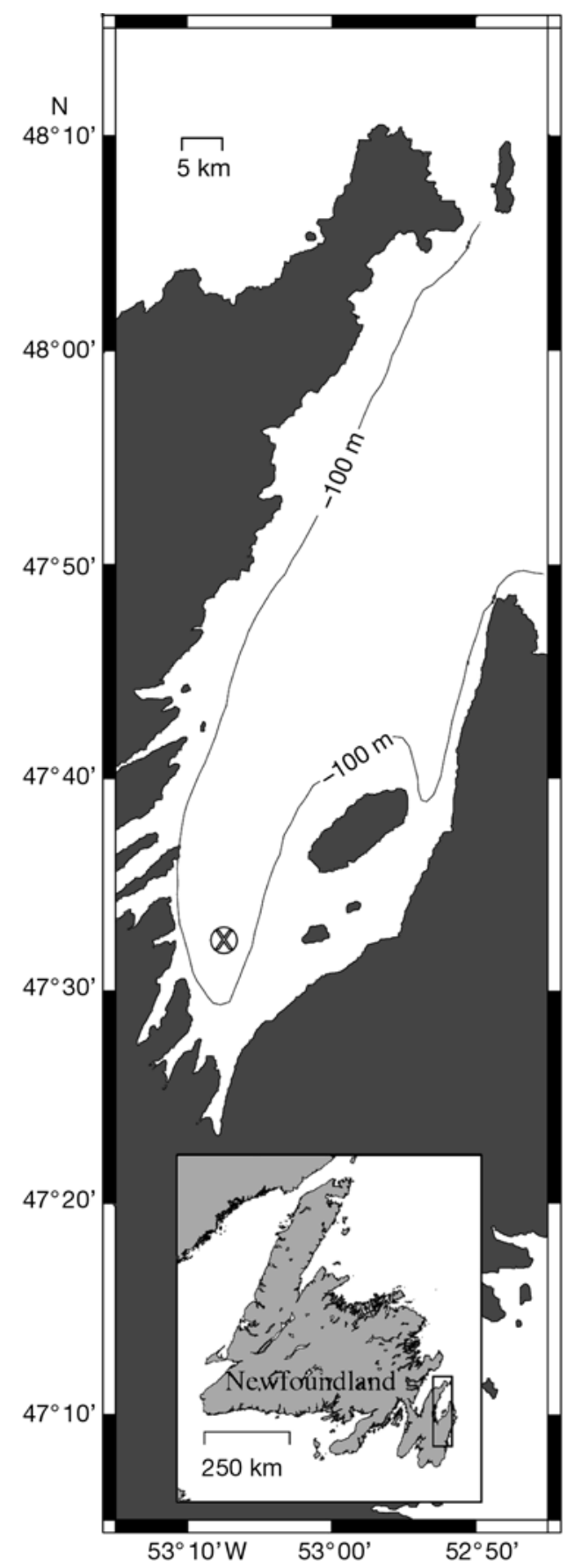

Fig. 1. Site of the sediment trap mooring in Conception Bay, Newfoundland (depth $270 \mathrm{~m}$ )

Conception Bay despite the low temperature, consistent with subsequent reports of high rates of organic carbon utilization in Arctic fjords and Antarctic shelf waters (Glud et al. 1998, Baldwin \& Smith 2003, Mincks et al. 2005). Because of the mid-latitude light regime, we hypothesized that the diatom bloom in Conception Bay should begin before the onset of thermal stratification and therefore at very low water tem- 
peratures, leading to suppression of bacterial and mesozooplankton utilization of phytoplankton production in the water column and to high flux of diatom biomass to the bottom. Conversely, in those years when meteorological and hydrographic factors either delay or prolong the spring bloom, utilization of phytodetritus by water column heterotrophs should be greater (Townsend et al. 1994). According to Rysgaard et al. (1998), much of the literature on benthic-pelagic coupling concerns warm, shallow water with a seasonal cycle in bottom water temperature (Olesen 1995, Heiskanen \& Leppänen 1995), complicating interpretation of heterotrophic response data. In contrast, water temperature below $80 \mathrm{~m}$ depth varies little in Conception Bay throughout the year, and the entire water column remains $<0^{\circ} \mathrm{C}$ throughout the formation and sinking of the spring phytoplankton bloom (Parrish et al. 2005). In this study, we determined the vertical flux of particulate matter in order to estimate the input of energy to the benthos of Conception Bay during spring and to test our hypotheses concerning pelagic utilization of the bloom. This work was conducted as part of the Cold Ocean Productivity Experiment (COPE), an international research program to investigate heterotrophic utilization of the spring bloom at low water temperatures. Although there is considerable information from temperate and tropical waters, pelagic-benthic energy coupling is poorly documented in sub-arctic regions, largely because of strong seasonal variation in climatic forcing and primary production as well as an incomplete understanding of food web structure and dynamics (Beaulieu 2002, Hobson et al. 2002, Wassmann et al. 2004). the surface) for periods of 3 to $7 \mathrm{~d}$, with one $13 \mathrm{~d}$ deployment during early April due to a prolonged storm (Table 1). Traps were retrieved 10 times between 29 March and 30 May. At each retrieval, and on other sampling dates when traps were not retrieved, vertical profiles of water column properties were recorded (SeaBird SBE 25 CTD fitted with a SeaTech in situ fluorometer). CTD data were smoothed into $2 \mathrm{~m}$ bins before contour plotting. Relative fluorescence units were converted to chlorophyll (chl) a concentrations using a regression equation based on samples from Conception Bay (Ostrom et al. 1997).

During the first 5 trap deployments, 2 traps of each quartet at 40,80 , and $150 \mathrm{~m}$ were covered with plastic screens (1.8 mm mesh) to exclude 'swimmers' while permitting diatom chains, flocs, and fecal pellets to enter. No significant differences $(p>0.05)$ were obtained in the mean value for any variable between traps with screens and those without (data not shown), so the practice of using screens was discontinued in later deployments, and data from traps with and without screens were pooled before statistical analyses and plotting. Poisons were not used, as the duration of deployment was short, and water temperatures were low. Furthermore, poisons interfere with the chemical analyses of samples, e.g. by partial destruction of chl a (Olesen 1995), and increase the number of swimmers retained (Olesen 1995, Parrish et al. 2005). Other studies in this region suggest that omitting poisons results in a loss of $<10 \%$ of particulate organic carbon (POC) and greatly reduces variability due to the elimination of zooplankton swimmers (Parrish et al. 2005). Recent publications have recommended non-poisoned

\section{MATERIALS AND METHODS}

Vertical flux. The vertical flux of particulate material was determined with sediment traps moored at a site within the deep depositional area of Conception Bay, before, during, and after the spring phytoplankton bloom in 1988 (Fig. 1). A series of traps was attached to a taut-wire mooring at a site $270 \mathrm{~m}$ deep (Fig. 1). The traps were $60 \times 10 \mathrm{~cm}$ PVC cylinders (Bloesch \& Burns 1980), giving a collection efficiency equivalent to that of funnel traps with baffles (Hargrave \& Burns 1979). Arrays of 4 replicate traps equally spaced on the circumference of a circle with a diameter of $1 \mathrm{~m}$ were deployed at each of 4 depths $(40,80,150$, and $240 \mathrm{~m}$ below
Table 1. Trap deployment information. Traps were deployed in quadruplicate on a taut-wire train wheel mooring at 4 depths $(40,80,150$, and $240 \mathrm{~m}$ below surface) in Conception Bay, Newfoundland. The maximum temperature shown is the mean temperature at the near surface $(40 \mathrm{~m})$ trap during each deployment as determined with a Seabird SBE-25 CTD (see 'Materials and methods'). The maximum temperatures recorded at all other trap depths were less than this near-surface value. The letter code for the various deployments $(\mathrm{A}-\mathrm{J})$ is for cross-reference to Figs. 2 to 5

\begin{tabular}{|lccccc|}
\hline $\begin{array}{l}\text { Sequential } \\
\text { deployment } \\
\text { number }\end{array}$ & $\begin{array}{c}\text { Maximum } \\
\text { temperature } \\
\left({ }^{\circ} \mathrm{C}\right)\end{array}$ & $\begin{array}{c}\text { Date trap Date trap } \\
\text { deployed }\end{array}$ & $\begin{array}{c}\text { Elapsed time } \\
\text { retrieved deployment } \\
(\mathrm{d})\end{array}$ & $\begin{array}{c}\text { Deployment } \\
\text { code }\end{array}$ \\
\hline 01 & -1.03 & 29 March & 6 April & 8 & $\mathrm{~A}$ \\
02 & -0.32 & 6 April & 19 April & 13 & $\mathrm{~B}$ \\
03 & -0.33 & 19 April & 22 April & 3 & $\mathrm{C}$ \\
04 & -0.91 & 22 April & 27 April & 5 & $\mathrm{D}$ \\
05 & -0.66 & 27 April & 4 May & 7 & $\mathrm{E}$ \\
06 & 0.19 & 4 May & 10 May & 6 & $\mathrm{~F}$ \\
07 & 0.64 & 10 May & 13 May & 3 & $\mathrm{G}$ \\
08 & -0.56 & 13 May & 17 May & 4 & $\mathrm{H}$ \\
09 & -0.14 & 17 May & 25 May & 8 & $\mathrm{I}$ \\
10 & -0.77 & 25 May & 30 May & 5 & $\mathrm{~J}$ \\
\hline
\end{tabular}


traps for flux studies in cold water (Tamelander \& Heiskanen 2004, Wassmann et al. 2004).

One hour after trap recovery, the bulk of the supernatant from each collection tube was slowly decanted and discarded, taking care not to disturb the settled material. The remaining supernatant and contents were returned to the laboratory in polycarbonate bottles packed in ice. Zooplankton were removed from the samples, which were then allowed to settle overnight on ice. The supernatant was again carefully decanted, as described above, and the remaining slurry made up to 50 or $100 \mathrm{ml}$ with filtered seawater (1 $\mu \mathrm{m}$ in-line cartridge filter). The slurry was thoroughly mixed by gentle shaking, and subsamples were removed for analysis.

Ideally, flux measurements based on sediment trap data should be made in environments with low current velocities, to avoid resuspension of benthic material and hydrodynamic interactions between turbulent flow fields and the mouth of the trap, and to minimize small horizontal gradients in the concentration of sinking particles. Mean current velocities at $25 \mathrm{~m}$ depth near the trap mooring in Conception Bay in spring and summer are low $\left(<2 \mathrm{~cm} \mathrm{~s}^{-1}\right)$ and cause negligible net horizontal transport (deYoung \& Sanderson 1995). Tidal currents do not play a major role in water mass exchange or in the mean circulation in Conception Bay, and the residence time of surface water near the trap mooring is about $30 \mathrm{~d}$ (deYoung \& Sanderson 1995). Near the western shore of the bay, to the west of the trap mooring, currents are weak, variable, and oriented parallel to the isobaths, suggesting that advection from coastal waters into the deep depositional area is unlikely. The mean circulation pattern is generally cyclonic (deYoung \& Sanderson 1995), suggesting that to the east of the trap mooring current flow is directed away from the study site (Fig. 1). Current velocities at $200 \mathrm{~m}$ are generally lower than at the surface (i.e. mean velocities are $<2.3 \mathrm{~cm} \mathrm{~s}^{-1}$, deYoung \& Sanderson 1995) and well below the threshold of $15 \mathrm{~cm}$ $\mathrm{s}^{-1}$ above which the efficiency of sediment traps declines rapidly (Baker et al. 1988). Several years of transmissometer data indicate that the nepheloid layer extends to ca. $70 \mathrm{~m}$ above bottom (authors' unpubl. data). In those years in which multiple sediment trap moorings were deployed in Conception Bay, there was strong coherence between the inner and outer bay in both the timing and magnitude of vertical flux events (Ostrom et al. 1997). Thus data collected at our mooring site is generally representative of the timing and magnitude of vertical flux throughout the bay.

Particulate organic carbon, particulate organic nitrogen (PON), and pigments. For the determination of POC and PON, subsamples of trap material were collected under vacuum on pre-combusted Whatman
$\mathrm{GF} / \mathrm{C}$ filters (25 mm diameter), dried at $60^{\circ} \mathrm{C}$, and combusted in a Perkin-Elmer $240 \mathrm{CHN}$ analyzer. No correction was made for carbonates, as microscopy of trap contents revealed few shell-bearing organisms and previous checks had indicated that carbonates represented $<10 \%$ of total particulate carbon. The same filtration process was used for the determination of dry weight of particulate matter and weight loss on ignition at $450^{\circ} \mathrm{C}$, except that material on the filter was washed with $2 \mathrm{ml}$ of $3 \%$ ammonium formate before drying.

Water samples for chloropigment determination were collected on $25 \mathrm{~mm}$ Whatman GF/C filters under low vacuum and analyzed immediately or following storage in darkness at $-70^{\circ} \mathrm{C}$ for up to 6 wk (Redden et al. 1993). Pigments were extracted overnight in $90 \%$ acetone at $4^{\circ} \mathrm{C}$ in darkness. Chl $\mathrm{a}$ and phaeopigments were determined by fluorometry, and 1 sample from each set of 4 replicates was also analyzed by HPLC (Redden et al. 1993) to check for systematic errors in fluorometric results due to interference from chl $b$, from breakdown products of chloropigments often found in zooplankton feces, or from other nonchlorophyllous, fluorescent material. Redden et al. (1993) found very good agreement between fluorescence and HPLC methods for chl a-like pigments and phaeopigments extracted from algal cultures and mussel feces, with no elevation of the baseline in the HPLC profiles. For routine work we therefore measured chl $a$ and total phaeopigments with a TurnerDesigns TD-10 fluorometer.

Microscopic analysis. For microscopic analysis, a $1 \mathrm{ml}$ subsample was removed from the sediment trap slurry and placed in a $20 \mathrm{ml}$ vial. One $\mathrm{ml}$ basic Lugol's iodine was added and the vial filled with the clear supernatant from the slurry bottle. After mixing, $1 \mathrm{ml}$ of fixed sample was removed and placed in an Utermöhl chamber. For phytoplankton and fecal pellet identification and enumeration, up to one-half of the resulting settled material was examined at $400 \times$ and 200× magnification with a Zeiss Axiovert 35 inverted microscope under phase-contrast illumination. At least 300 cells in each taxon or size class were counted. Phytoplankton and fecal pellet volume estimates were made with an ocular micrometer by approximation to common geometric shapes. Observed phytoplankton volume was corrected for cell shrinkage due to dehydration. Many of the fecal pellets were in various stages of disintegration, making volume estimation difficult. Phytoplankton (except diatoms) and fecal pellet volume were converted to carbon using the equation $\mathrm{C}$ $(\mathrm{pg})=$ volume $\left(\mu^{3}\right) \times 0.11$, while diatom volume was converted using $C(p g)=$ plasma volume $\left(\mu^{3}\right) \times 0.11$ (Strathmann 1967, Booth 1993). Taxonomic composition values for trap samples are expressed in this paper as relative percentages based on carbon mass, i.e. 
(mass of taxon or group / total mass of recognizable particles) $\times 100 \%$.

Water column samples for microscopic analysis were taken with 51 Niskin bottles. Subsamples $(250 \mathrm{ml})$ were fixed with basic Lugol's iodine (final concentration ca. $1 \%$ ) and stored in the dark at $5^{\circ} \mathrm{C}$. Further subsamples (2 to $100 \mathrm{ml}$, depending on cell abundance) were settled in Utermöhl chambers. Floristic analysis followed the Utermöhl method as detailed for the sediment trap samples above.

Inorganic nutrients. Additional water samples were removed from the Niskin bottles and stored in the dark on ice until inorganic nutrient analyses were completed, within $24 \mathrm{~h}$ of collection (Strickland \& Parsons 1972). Reactive silicate was determined by the molybdate method and nitrate by the sulfanilamide reaction.

First-order seasonal carbon budget. A first-order carbon budget for the $79 \mathrm{~d}$ period covering the formation and sinking of the spring phytoplankton bloom was constructed using a combination of data from Conception and Trinity Bays, Newfoundland, reported in this paper and previous publications outlined below. Here we present the sources of data and assumptions underlying the carbon budget.

The seasonal primary production rate of $45 \mathrm{~g} \mathrm{C} \mathrm{m}^{-2}$ was taken from this paper, in which the sources and assumptions are given. Daily utilization of organic carbon by bacteria in the water column was taken from bacterial biomass and production data for Conception Bay (Pomeroy et al. 1991), assuming a bacterial growth efficiency of $33 \%$, which is in the mid-range of values reported by these authors. Daily rates were temporally integrated by rectangular interpolation. Utilization of organic carbon by water column mesozooplankton was based on zooplankton biomass information for Conception Bay (Tian et al. 2003), assuming a mesozooplankton daily ration of $30 \%$ of body carbon from copepod ingestion rate data for Conception Bay (Redden 1994), and an assimilation ratio of $70 \%$ derived from a synthesis of literature on copepods and appendicularian tunicates. The zooplankton biomass value used was $0.5 \mathrm{~g} \mathrm{C} \mathrm{m}^{-2}$ (note error in units in the original figure of Tian et al. 2003), which is a conservative estimate for Conception Bay (see Discussion). Daily zooplankton carbon utilization was multiplied by $79 \mathrm{~d}$ to cover the entire sinking period. The estimated benthic flux of organic carbon was derived from the sediment trap data presented here.

Utilization of organic carbon by anaerobic benthic microbes was taken from data for Conception Bay sediments (Pomeroy et al. 1991), assuming a bacterial growth efficiency of $33 \%$, the mid-range of values recommended by Pomeroy et al. (1991). Aerobic benthic microbial utilization of organic carbon was estimated assuming a benthic respiration rate of $107 \mathrm{mg} \mathrm{C} \mathrm{m}^{-2} \mathrm{~d}^{-1}$ and a bacterial growth efficiency of $33 \%$, both from Conception Bay sediment data (Pomeroy et al. 1991). The result was a benthic microbial utilization rate of $162 \mathrm{mgC} \mathrm{m}^{-2} \mathrm{~d}^{-1}$, or $19 \mathrm{~g} \mathrm{C} \mathrm{m}^{-2}$ for the $79 \mathrm{~d}$ sinking period, assuming a constant proportion of benthic aerobic utilization of the sinking material over the entire sinking period (G. T. Rowe pers. comm.).

Utilization of organic carbon by suprabenthic zooplankton was estimated assuming an abundance of 200 Pseudocalanus spp. $\mathrm{m}^{-2}$ (primarily copepodite stage IV with a mass of $3.5 \mu \mathrm{gC}$ animal ${ }^{-1}$ ) and 25 Calanus spp. $\mathrm{m}^{-2}$, most of which were copepodite stage IV with a mean mass of $50 \mu \mathrm{gC}$ animal $^{-1}$ (Choe \& Deibel 2000). A daily ration of $30 \%$ was assumed for suprabenthic copepods, as for water column copepods (see above). Daily carbon utilization rates were multiplied by $79 \mathrm{~d}$. Mysids are also abundant in the benthic boundary layer, and their utilization of organic carbon was calculated from abundance and biomass data from sledge tows in Conception Bay (Richoux et al. 2004c). We assumed a daily ration of $30 \%$ of body weight for mysids and an assimilation ratio of $70 \%$. Daily carbon utilization rates were multiplied by $79 \mathrm{~d}$. The carbon utilization by suprabenthic zooplankton was the sum of the above rates for suprabenthic copepods and mysids.

Utilization of organic carbon by macrobenthos was based upon a macrobenthic biomass of $5 \mathrm{gC} \mathrm{m}^{-2}$ for Conception Bay (Scheibe 1991), and a daily ration of $1 \%$ and assimilation ratio of $70 \%$ for Conception Bay macrobenthos (Stead et al. 2003). Daily rates of carbon utilization were multiplied by $79 \mathrm{~d}$.

\section{RESULTS}

\section{Water column properties}

The first sustained doubling of winter chl a values was established at ca. $15 \mathrm{~m}$ depth on 23 to 24 March, marking the initiation of the spring bloom. There was no thermal stratification at this time, with temperatures $<0^{\circ} \mathrm{C}$ from surface to bottom (Fig. 2a). However, there was a density difference of 0.3 between the surface and $70 \mathrm{~m}$ depth (Fig. 2b) because the surface water was less saline. Silicate values in the upper mixed layer (UML) were ca. 40\% lower in late March than in winter (Fig. 2e). A strong and sustained storm during the first 2 wk of April terminated the nascent bloom (Fig. $2 \mathrm{a}-\mathrm{c}$ ). Following relaxation of the wind stress, the peak magnitude of chl a reached ca. $2.5 \mu \mathrm{g} \mathrm{l}^{-1}$ at $30 \mathrm{~m}$ depth on 2 to 3 May. Surface heating contributed to increasing stratification during the first $3 \mathrm{wk}$ of May (Fig. 2a,b), accompanied by a reduction of surface silicate from 4.0 to $<0.5 \mu \mathrm{M}$ and a deepening of the sub- 

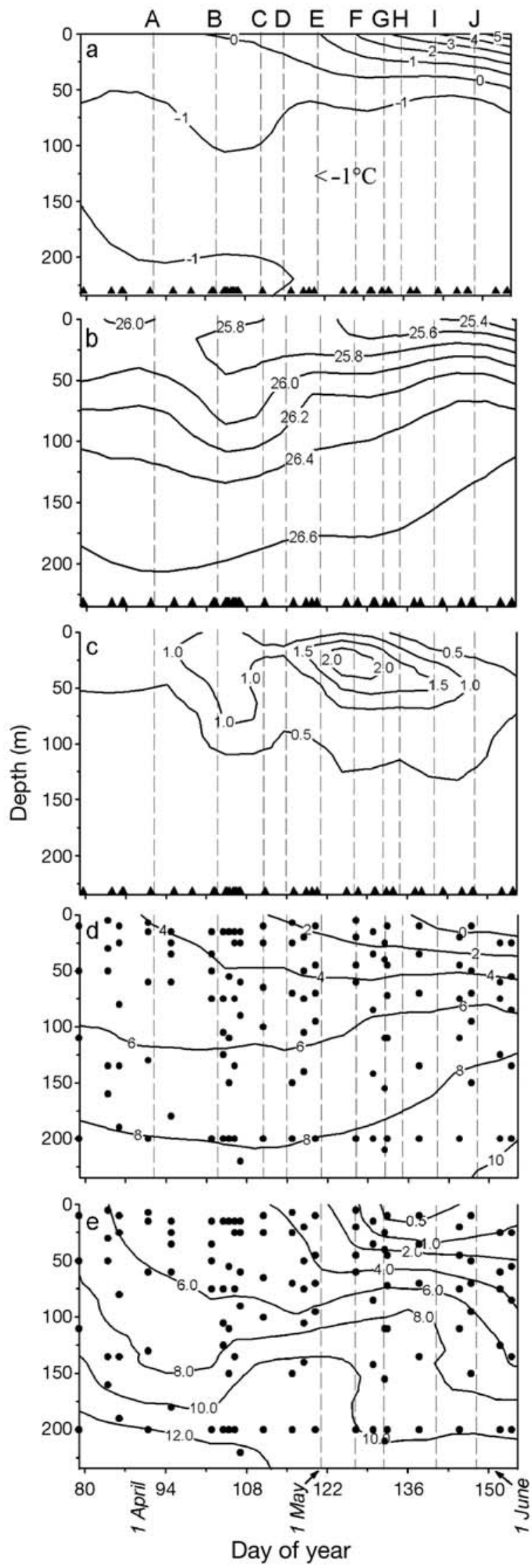

Fig. 2. Time-depth plots of hydrographic and inorganic nutrient data during the sediment trap deployments in Conception Bay. A to J and vertical dotted lines mark the retrieval of trap samples (details in Table 1). (a) Temperature $\left({ }^{\circ} \mathrm{C}\right.$ ), (b) density (sigma-t), (c) in situ chl a $\left(\mu \mathrm{g} \mathrm{l}^{-1}\right)$. See 'Materials and methods' for the conversion of relative fluorescence units to units of chl $a$. Black triangles on the $x$-axes of $(\mathrm{a}-\mathrm{c})$ indicate time of CTD casts. (d) Nitrate $(\mu M)$, (e) silicate $(\mu M)$. Filled circles in (d) and (e) indicate the depths at which water samples were taken with Niskin bottles

surface chlorophyll maximum (SCM) from 30 to $>50 \mathrm{~m}$ depth (Fig. 2c). There was evidence of higher concentrations of chl $a$ in the deep water mass from the last week in April through the first half of May. The SCM fell below $0.8 \mu \mathrm{g} \mathrm{chl} \mathrm{a} \mathrm{l}^{-1}$ on 27 May, about 2 mo after the bloom began (Fig. 2c). During sinking of the bloom, the SCM was never located in water $>0^{\circ} \mathrm{C}$ (Fig. 2a,c).

The storm in early April greatly modified the composition of the phytoplankton community. Biomass of the pre-bloom community was dominated by unarmored dinoflagellates and ciliates. At the beginning of the bloom in late March, diatoms increased in abundance relative to flagellates in the upper $25 \mathrm{~m}$. The diatom community was dominated primarily by Chaetoceros debilis, with a secondary contribution from Skeletonema costatum. The storm resulted in the reestablishment of a pre-bloom, flagellate-dominated phytoplankton community. Following the storm, diatoms once again increased in numbers relative to flagellates, with diatom biomass accounting for $90 \%$ of total community carbon by the end of April. This was followed in May by accelerated sinking of diatoms and a relative increase in dinoflagellates in the UML, with dinoflagellate biomass reaching $>90 \%$ of total community carbon by the end of May. Although C. debilis, $C$. socialis and $S$. costatum were the most abundant diatoms during the spring bloom period, Thalassiosira nordenskioldii, T. gravida, T. subtilis, and Coscinodiscus spp. dominated carbon mass, often making up 40 to $60 \%$ of total diatom biomass. Thalassiosira spp. and Coscinodiscus spp. dominated biomass at depths below $25 \mathrm{~m}$ during the second half of the bloom period.

\section{Particle flux}

At depths of 40,80, and $150 \mathrm{~m}$, daily fluxes of total particulate matter (TPM) were 1 to $3 \mathrm{~g} \mathrm{~m}^{-2} \mathrm{~d}^{-1}$ throughout April (samples A to E), increasing to $>4 \mathrm{~g} \mathrm{~m}^{-2} \mathrm{~d}^{-1}$ in samples F and G in early May (Fig. 3). Organic content of the trap material at 40 and $80 \mathrm{~m}$ was $15-28 \%$ during April and 30-52\% in May, the highest levels occurring from 4 to 10 May (sample F). During the second half of May, the sinking SCM had reached depths $>40 \mathrm{~m}$ 


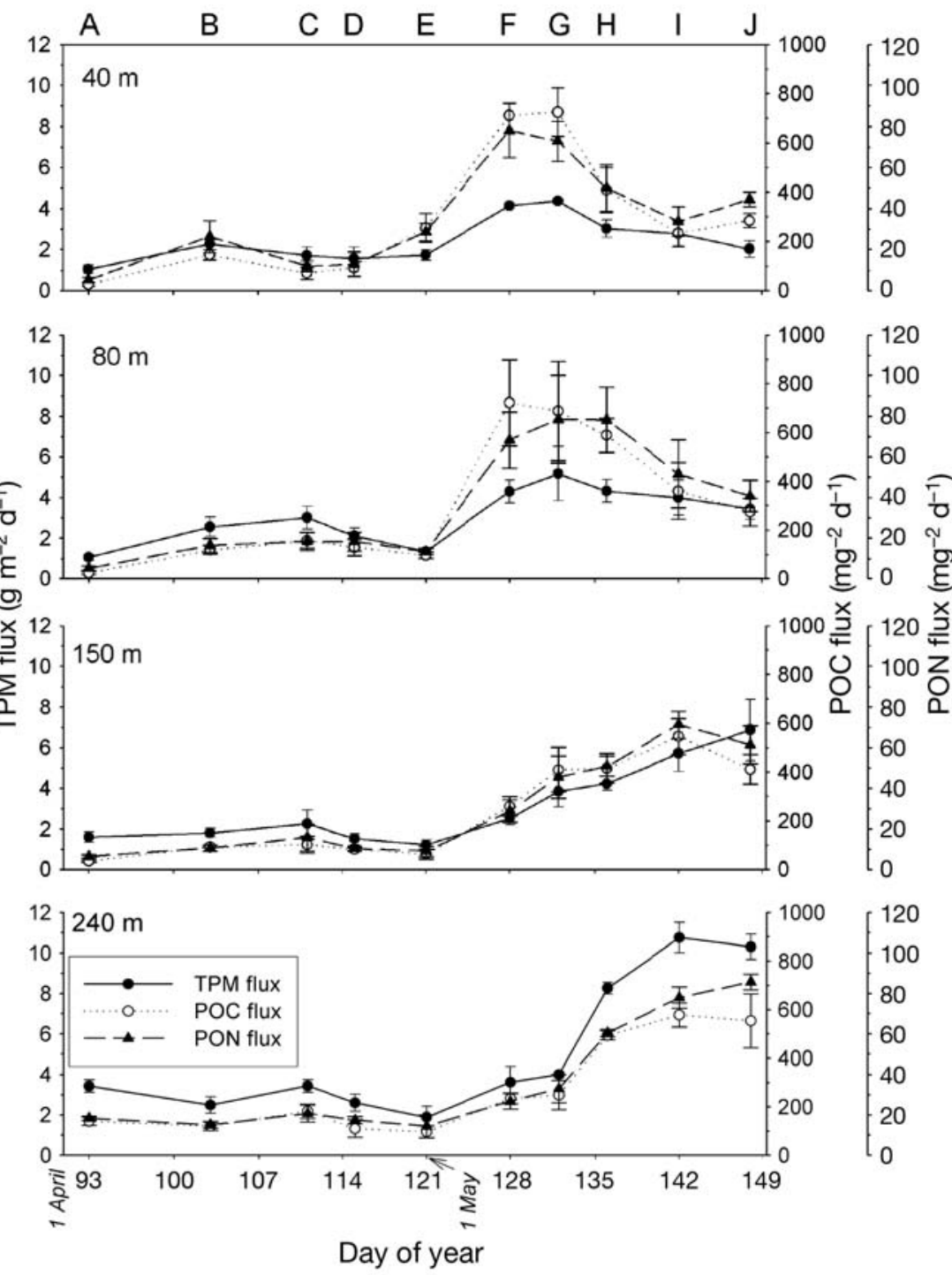

Fig. 3. Mean vertical flux ( $\pm 1 \mathrm{SD}$ of 4 replicates at each depth) of total particulate matter (TPM, dry weight), particulate organic carbon (POC), and particulate organic nitrogen (PON) vs. day of the year in traps at 40,80,150, and $240 \mathrm{~m}$ depth. A to $\mathrm{J}$ are explained in the legend for Table 1 trap, located $30 \mathrm{~m}$ above bottom (mab), but not the $150 \mathrm{~m}$ trap at $120 \mathrm{mab}$. The organic content of the TPM in the $240 \mathrm{~m}$ trap reached a maximum of ca. $23 \%$ in sample F in early May. At all depths, both mean TPM flux and mean organic content were significantly higher during the sinking event than before it (Table 2), indicating that sedimentation of organic material and not resuspension was responsible for much of the increase in TPM flux at $240 \mathrm{~m}$ (Fig. 3). However, there was a significant decrease in percent organic content with increasing trap depth during the sinking event, which was not observed during the pre-event period (Table 2).

Daily fluxes of POC at depths of 40 , 80 , and $150 \mathrm{~m}$ were $<35 \mathrm{mg} \mathrm{m}^{-2} \mathrm{~d}^{-1}$ during the first trap deployment (sample A), suggesting little flux of bloom material prior to April (Fig. 3). POC flux increased during April but remained $<220 \mathrm{mg} \mathrm{m}^{-2} \mathrm{~d}^{-1}$ at all trap depths until early May. The sinking event was marked by a sudden increase in POC flux during the first week of May at all 4 trap depths (sample F), peaking at $>700 \mathrm{mgC} \mathrm{m}^{-2} \mathrm{~d}^{-1}$ at 40 and $80 \mathrm{~m}$ (Fig. 3). During midMay (samples G to I) POC flux to these depths decreased, reaching 200 to $300 \mathrm{mg} \mathrm{m}^{-2} \mathrm{~d}^{-1}$ by the end of May. POC fluxes $>400 \mathrm{mgC} \mathrm{m}^{-2} \mathrm{~d}^{-1}$ were maintained at 150 and $240 \mathrm{~m}$ from midto late May (samples $\mathrm{H}$ to J), with peak values during the third week in May (550-600 $\mathrm{mg} \mathrm{m}^{-2} \mathrm{~d}^{-1}$; sample I). POC fluxes to $240 \mathrm{~m}$ were frequently higher than those to $150 \mathrm{~m}$, presumably due to POC inputs from resuspended bottom

(Fig. 2c), resulting in significantly greater TPM flux at $80 \mathrm{~m}$ than at $40 \mathrm{~m}$ (Table 2, Fig. 3). At $150 \mathrm{~m}$, there was a 7 -fold increase in TPM flux at the end of May (samples F to J), with an increasing trend to the end of the time series (Fig. 3). A gradual doubling of the organic content occurred from ca. $15 \%$ in early April to ca. $30 \%$ in early May. At $240 \mathrm{~m}$, a rapid increase in TPM flux was observed in mid-May (sample H), increasing to ca. $11 \mathrm{~g} \mathrm{~m}^{-2}$ $\mathrm{d}^{-1}$ in the third week of May (samples I and J; Fig. 3). TPM flux at $240 \mathrm{~m}$ was always significantly higher than at $150 \mathrm{~m}$ (Table 2), due in part to resuspension. In situ transmissometer readings showed high levels of suspended particles at depths below $200 \mathrm{~m}$, indicating that resuspension periodically reached the level of the $240 \mathrm{~m}$ sediments and/or to other sources such as zooplankton fecal pellets released below $150 \mathrm{~m}$. The daily flux of PON followed a similar time course to that of POC (Fig. 3). PON flux increased from $<15 \mathrm{mg} \mathrm{m}^{-2} \mathrm{~d}^{-1}$ at all trap depths in April to $>70 \mathrm{mg} \mathrm{m}^{-2} \mathrm{~d}^{-1}$ at 40 and $80 \mathrm{~m}$ in early May (samples F and G; Fig. 3). PON flux at 150 and $240 \mathrm{~m}$ also increased in early May, but reached a maximum later than in the surface traps, with fluxes of 60-90 $\mathrm{mg} \mathrm{m}^{-2} \mathrm{~d}^{-1}$ in samples I and J. Although the mean fluxes of POC and PON before the sinking event were higher between 150 and $240 \mathrm{~m}$ than they were in the upper water column, mean fluxes of POC and PON at all trap depths were equal during the sinking event (Table 2). 
Table 2. Mean particle flux (with 95\% CL) in Conception Bay, Newfoundland, determined by sediment traps at 4 depths. The sampling period extended from 29 March to 30 May. The number of measurements included in each mean (i.e. sample ' $n$ ') ranged from 16 to 24 depending on the variable and depth. 'Pre' refers to the time series before the main sinking event, while 'Event' refers to the main sinking event. 'Pre' and 'Event' were inferred from Figs. $3 \& 4$. Within each column, mean values sharing the same superscripts are not significantly different ( $p>0.05$; ANOVA followed by post hoc Hochberg GT-2 or Dunnett's T-3 test). Within depths, mean values before and during the main sinking event were significantly different for each constituent $(p<0.05)$. TPM: total particulate dry matter; \% org: organic matter as a percentage of total particulate dry matter determined by weight loss on ignition; POC: particulate organic carbon; PON: particulate organic nitrogen

\begin{tabular}{|c|c|c|c|c|c|c|c|c|}
\hline \multirow{2}{*}{$\begin{array}{l}\text { Depth } \\
\text { (m) }\end{array}$} & \multicolumn{2}{|c|}{$\mathrm{TPM}\left(\mathrm{g} \mathrm{m}^{-2} \mathrm{~d}^{-1}\right)$} & \multicolumn{2}{|c|}{$\%$ org } & \multicolumn{2}{|c|}{ POC $\left(\mathrm{mgC} \mathrm{m}^{-2} \mathrm{~d}^{-1}\right)$} & \multicolumn{2}{|c|}{ PON $\left(\mathrm{mgN} \mathrm{m}^{-2} \mathrm{~d}^{-1}\right)$} \\
\hline & Pre & Event & Pre & Event & Pre & Event & Pre & Event \\
\hline \multirow[t]{2}{*}{40} & $1.65^{\mathrm{a}}$ & $3.26^{\mathrm{a}}$ & $21.7^{\mathrm{a}}$ & $40.7^{\mathrm{a}}$ & $73.9^{\mathrm{a}}$ & $404^{\mathrm{a}}$ & $12.3^{\mathrm{a}, \mathrm{b}}$ & $51.2^{\mathrm{a}}$ \\
\hline & $(1.44-1.87)$ & $(2.84-3.69)$ & $(19.0-24.3)$ & $(37.9-43.4)$ & $(47.0-101)$ & $(313-495)$ & $(7.68-17.0)$ & $(43.0-59.4)$ \\
\hline \multirow[t]{2}{*}{80} & $2.01^{\mathrm{a}}$ & $4.24^{\mathrm{b}}$ & $21.4^{\mathrm{a}, \mathrm{b}}$ & $35.1^{\mathrm{b}}$ & $104^{a, b}$ & $516^{a}$ & $14.1^{\mathrm{a}, \mathrm{b}}$ & $63.5^{\mathrm{a}}$ \\
\hline & $(1.66-2.37)$ & $(3.83-4.65)$ & $(17.9-24.8)$ & $(32.9-37.3)$ & $(79.2-128)$ & $(418-614)$ & $(11.3-16.9)$ & $(54.3-72.6)$ \\
\hline \multirow[t]{2}{*}{150} & $1.68^{\mathrm{a}}$ & $4.63^{\mathrm{b}}$ & $19.3^{\mathrm{a}, \mathrm{b}}$ & $27.2^{\mathrm{c}}$ & $72.4^{\mathrm{a}}$ & $408^{\mathrm{a}}$ & $10.1^{\mathrm{a}}$ & $50.5^{\mathrm{a}}$ \\
\hline & $(1.46-1.89)$ & $(3.87-5.39)$ & $(18.3-20.3)$ & $(25.5-28.9)$ & $(58.3-86.5)$ & $(359-457)$ & $(8.1-12.0)$ & $(42.9-58.1)$ \\
\hline \multirow[t]{2}{*}{240} & $2.77^{\mathrm{b}}$ & $\begin{array}{c}7.57^{\mathrm{c}} \\
(69)\end{array}$ & $16.9^{\mathrm{b}}$ & $20.2^{\mathrm{d}}$ & $130^{\mathrm{b}}$ & $422^{\mathrm{a}}$ & $17.3^{\mathrm{b}}$ & $53.3^{\mathrm{a}}$ \\
\hline & $(2.46-3.08)$ & $(6.15-8.98)$ & $(15.0-18.8)$ & $(19.2-21.1)$ & $(113-148)$ & $(347-497)$ & $(14.1-18.8)$ & $(41.8-65.0)$ \\
\hline
\end{tabular}

\section{Pigment flux}

Silicate and nitrate levels in the UML at the time sampling began were lower than in deeper water, indicating that the spring phytoplankton bloom had begun earlier (Fig. 2d,e). However, the first trap sample (A) was clearly taken before any sinking of spring phytoplankton had taken place (Fig. 4). Daily fluxes of total chloropigments (Tchl, i.e. chl a + phaeopigments, determined from fluorometric analysis before acidification of the sample) were $<0.5 \mathrm{mg} \mathrm{m}^{-2} \mathrm{~d}^{-1}$ during the first trap deployment in late March (sample A). During the next $18 \mathrm{~d}$, fluxes of Tchl increased 3- to 4 -fold at all trap depths (samples B and C), followed by further increases after the storm, beginning at the end of April at $40 \mathrm{~m}$ (sample E) and in early May at all other depths (sample F; Fig. 4). Peak fluxes $>10 \mathrm{mg}$ Tchl m $\mathrm{m}^{-2} \mathrm{~d}^{-1}$ occurred at depths of 40 and $80 \mathrm{~m}$ during early to mid-May, with the highest values often observed at $80 \mathrm{~m}$. In late May, Tchl flux decreased to about $5 \mathrm{mg} \mathrm{m}^{-2} \mathrm{~d}^{-1}$ at 40 and $80 \mathrm{~m}$. The accumulation rates of Tchl in traps at $150 \mathrm{~m}$ were similar to those at $240 \mathrm{~m}$, with maxima of ca. $8 \mathrm{mg} \mathrm{m}^{-2} \mathrm{~d}^{-1}$ (Fig. 4). There was a time lag as the Tchl flux maximum reached each depth, with maxima occurring in sample $\mathrm{F}$ at $40 \mathrm{~m}$, sample $\mathrm{G}$ at $80 \mathrm{~m}$, samples $\mathrm{G}$ and $\mathrm{H}$ at $150 \mathrm{~m}$, and sample $\mathrm{H}$ at $240 \mathrm{~m}$ (Fig. 4). The mean flux of Tchl was not statistically different among the trap depths before the sinking event, whereas during the event Tchl flux at $80 \mathrm{~m}$ was significantly greater than at $240 \mathrm{~m}$ (Table 3).
The composition of the chloropigment pool varied seasonally and with depth (Fig. 4). Phaeopigments made a larger contribution to Tchl than did chl $a$ at all depths during the first 3 wk of April. Chl a flux began to increase in late April at $40 \mathrm{~m}$ depth (sample E) and in early May in deeper water (sample F). Values of $>8 \mathrm{mg}$ $\mathrm{m}^{-2} \mathrm{~d}^{-1}$ were recorded at 40 and $80 \mathrm{~m}$ in May, exceeding phaeopigment flux for the entire month at these depths (Fig. 4). Chl a flux reached 2-4 $\mathrm{mg} \mathrm{m}^{-2} \mathrm{~d}^{-1}$ at 150 and $240 \mathrm{~m}$ (samples $\mathrm{F}$ to $\mathrm{H}$ ), exceeding phaeopigment flux only in sample $\mathrm{G}$ at $150 \mathrm{~m}$. During the middle of May, chl a decreased with increasing depth from a maximum of $80 \%$ of Tchl at $40 \mathrm{~m}$ to $30-40 \%$ at $240 \mathrm{~m}$. The mean flux of both chl $a$ and phaeopigments was significantly greater at all trap depths during the sinking event than before it (Table 3). However, the mean flux of phaeopigments below $40 \mathrm{~m}$ did not vary with depth either before or during the sinking event,

Table 3. Mean pigment flux (mg m ${ }^{-2} \mathrm{~d}^{-1}$, with $95 \% \mathrm{CL}$ ) in Conception Bay, Newfoundland, determined by sediment traps at 4 depths. For details see legend for Table 2. At 80,150 and $240 \mathrm{~m}$ depths, the phaeopigment pool was dominated by pyrophaeophorbide $a$, an indicator of copepod grazing of phytoplankton (Redden 1994). Phaeophorbide $a$ and phaeophytin a made little contribution to the vertical flux of phaeopigments. Tchl: total chloropigments; Chl a: chlorophyll $a_{\text {; }}$ Phaeo: phaeopigments

\begin{tabular}{|c|c|c|c|c|c|c|}
\hline \multirow{2}{*}{$\begin{array}{l}\text { Depth } \\
\text { (m) }\end{array}$} & \multicolumn{2}{|c|}{ Tchl } & \multicolumn{2}{|c|}{ Chl $a$} & \multicolumn{2}{|c|}{ Phaeo } \\
\hline & Pre & Event & Pre & Event & Pre & Event \\
\hline 40 & $1.28^{\mathrm{a}}$ & $7.06^{\mathrm{a}, \mathrm{b}}$ & $0.35^{\mathrm{a}}$ & $5.07^{a}$ & $0.93^{\mathrm{a}}$ & $2.15^{\mathrm{a}}$ \\
\hline & (0.95-1.61) & $(6.17-7.94)$ & $(0.25-0.45)$ & $(4.39-5.76)$ & $(0.68-1.17)$ & $2.38)$ \\
\hline 80 & $\begin{array}{c}2.04^{\mathrm{a}} \\
(1.60-2.48)\end{array}$ & $\begin{array}{c}9.09^{\mathrm{a}} \\
(7.24-10.9)\end{array}$ & $\begin{array}{c}0.70^{\mathrm{b}} \\
(0.51-0.90)\end{array}$ & $\begin{array}{c}5.63^{\mathrm{a}} \\
(4.16-7.10)\end{array}$ & $\begin{array}{c}1.34^{\mathrm{a}} \\
(1.06-1.62)\end{array}$ & $\begin{array}{c}3.46^{\mathrm{b}} \\
(3.04-3.88)\end{array}$ \\
\hline 150 & $\begin{array}{c}1.32^{\mathrm{a}} \\
(1.01-1.63)\end{array}$ & $\begin{array}{c}6.40^{\mathrm{a}, \mathrm{b}} \\
(5.77-7.05)\end{array}$ & $\begin{array}{c}0.28^{\mathrm{a}} \\
(0.20-0.35)\end{array}$ & $\begin{array}{c}3.00^{\mathrm{b}} \\
(2.53-3.46)\end{array}$ & $\begin{array}{c}1.04^{\mathrm{a}} \\
(0.80-1.28)\end{array}$ & $\begin{array}{c}3.42^{\mathrm{b}} \\
(3.11-3.73)\end{array}$ \\
\hline 240 & $\begin{array}{c}1.47^{\mathrm{a}} \\
(1.22-1.73)\end{array}$ & $\begin{array}{c}6.09^{\mathrm{b}} \\
(5.23-6.95)\end{array}$ & $\begin{array}{c}0.31^{\mathrm{a}} \\
(0.25-0.37)\end{array}$ & $\begin{array}{c}2.16^{\mathrm{c}} \\
(1.81-2.51)\end{array}$ & $\begin{array}{c}1.17^{\mathrm{a}} \\
(0.96-1.37)\end{array}$ & $\begin{array}{c}3.93^{\mathrm{b}} \\
(3.35-4.51)\end{array}$ \\
\hline
\end{tabular}




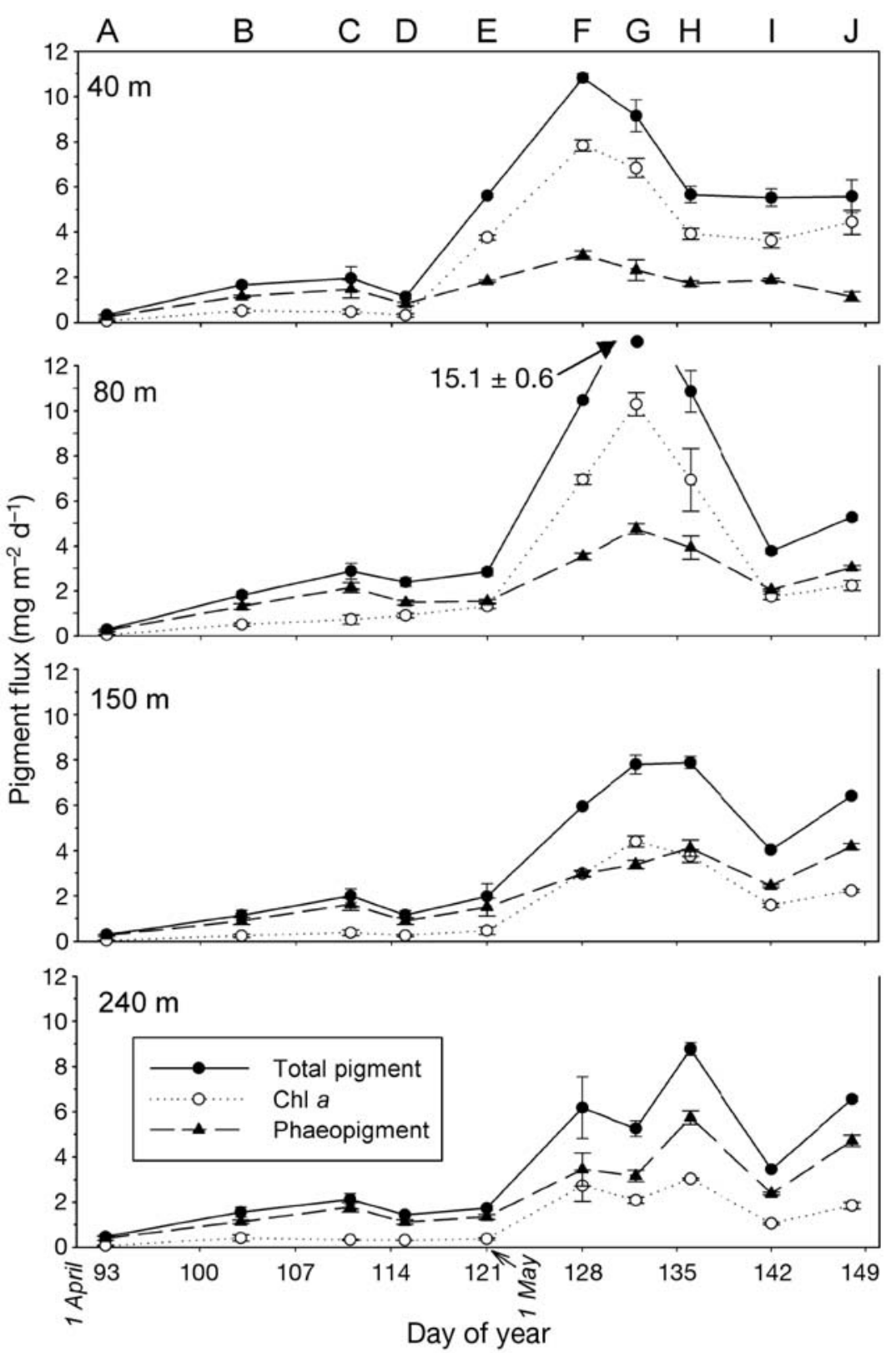

Fig. 4. Mean vertical flux $( \pm 1 \mathrm{SD}, \mathrm{n}=4)$ of total pigments (total chlorophylls + total phaeopigments), chl $a$, and total phaeopigments (primarily pyrophaeophorbide and phaeophytin a) vs. day of the year in traps at 40,80,150, and $240 \mathrm{~m}$ depth. A to J are explained in the legend for Table 1

while the mean flux of chl a was maximal at $80 \mathrm{~m}$, decreasing at 150 and $240 \mathrm{~m}$ both before and during the sinking event (Table 3 ). The decrease in mean chl a flux was greatest between 80 and $150 \mathrm{~m}$, ranging from $60 \%$ before the sinking event to ca. $47 \%$ during sinking. Pyrophaeophorbide $a+$ other phaeopigments made up about $60 \%$ of Tchl in surface sediments from 1 March to 12 September (Redden 1994), similar to material from $240 \mathrm{~m}$ traps during the sinking event (i.e. phaeopigments $=65 \%$ of Tchl, Table 3 ).

\section{Flux quality}

$\mathrm{C}: \mathrm{N}$ ratios for trap material $(\mathrm{w} / \mathrm{w})$ were $\leq 12$ throughout April and May, with maximum values at 40 and $80 \mathrm{~m}$ during the first week of May (sample F). Apart from the early phase of the bloom, there was no change in $\mathrm{C}: \mathrm{N}$ ratio with trap depth (Table 4). Throughout the bloom period, the C:N ratio of particulate material in traps at $240 \mathrm{~m}$ fell within a narrow range $(6.3$ to 8.8). C:N ratios were $\leq 5.7$ (w/w, i.e. the Redfield ratio) in the 40 and $80 \mathrm{~m}$ traps early in April and late in May. C:N ratios at 150 and $240 \mathrm{~m}$ varied little during the 8 wk study. Before the sinking event, the mean $C: N$ ratio of trap material at $40 \mathrm{~m}$ depth was essentially Redfield, but increased to constant, non-Redfield values of 6.9 to 7.7 at greater depths (Table 4). During the sinking event, the mean $\mathrm{C}: \mathrm{N}$ ratio at $40 \mathrm{~m}$ increased significantly to 9.0, indicating nitrate limitation of phytoplankton (Table 4). The mean C:N ratio did not increase with depth during the sinking event, ranging from 8.0 to 8.1 below $40 \mathrm{~m}$ (Table 4 ).

The sedimentation patterns of pigments reflected those of $\mathrm{POC}$, with little variability in the POC:Tchl ratio during sinking (Table 4). This ratio decreased gradually at all depths during April as pigment flux began to increase. The lowest ratios were recorded in traps below $40 \mathrm{~m}$ during late April and early May, when chl a flux was high as a result of cell senescence and massive diatom sinking (samples F to H, Fig. 4). The mean POC:Tchl ratio was independent of depth both before and after the sinking event, ranging from 58 to 123 (Table 4). Mean POC:chl a was significantly lower during the sinking event than before, increasing with depth during the sinking event from 82 at $40 \mathrm{~m}$ to 233 at $240 \mathrm{~m}$ (Table 4). Mean chl a content of the sinking material exceeded phaeopigment content only in the 40 and $80 \mathrm{~m}$ traps during the sinking event (Table 4). At all other depths and times, phaeopigments made up more than $50 \%$ of the sinking material. The importance of zooplankton grazing to phaeopigment flux was suggested by the predominance of pyrophaeophorbide $a$ in the phaeopigment pool. 
Table 4. Mean variable ratios (w/w, with $95 \%$ CL) for material from sediment traps at 4 depths in Conception Bay, Newfoundland. For further explanation see legends for Tables 2 and 3

\begin{tabular}{|c|c|c|c|c|c|c|c|c|}
\hline \multirow{2}{*}{$\begin{array}{l}\text { Depth } \\
\text { (m) }\end{array}$} & \multicolumn{2}{|c|}{$\mathrm{C}: \mathrm{N}$} & \multicolumn{2}{|c|}{ POC:Chl a } & \multicolumn{2}{|c|}{ POC:Tchl } & \multicolumn{2}{|c|}{ Phaeo:Chl a } \\
\hline & Pre & Event & Pre & Event & Pre & Event & Pre & Event \\
\hline 40 & $5.4^{\mathrm{a}}$ & $9.0^{\mathrm{a}}$ & $294^{\mathrm{a}}$ & $82^{\mathrm{a}}$ & $71^{\mathrm{a}}$ & $59^{a}$ & $3.0^{\mathrm{a}, \mathrm{b}}$ & $0.4^{\mathrm{a}}$ \\
\hline & $(4.8-5.9)$ & $(8.3-9.8)$ & $(231-358)$ & $(72-93)$ & $(56-87)$ & $(52-67)$ & $(2.5-3.6)$ & $(0.4-0.4)$ \\
\hline 80 & $6.9^{\mathrm{b}}$ & $8.0^{\mathrm{a}}$ & $299^{a}$ & $111^{a, b}$ & $64^{\mathrm{a}}$ & $58^{a}$ & $2.9^{\mathrm{a}}$ & $0.8^{\mathrm{b}}$ \\
\hline & $(6.2-7.6)$ & $(7.4-8.6)$ & $(184-414)$ & $(87-134)$ & $(56-72)$ & $(48-68)$ & $(1.9-3.9)$ & $(0.7-1.0)$ \\
\hline 150 & $7.1^{\mathrm{b}}$ & $8.1^{\mathrm{a}}$ & $442^{\mathrm{a}}$ & $164^{\mathrm{b}, \mathrm{c}}$ & $69^{\mathrm{a}}$ & $70^{\mathrm{a}}$ & $4.7^{\mathrm{b}}$ & $1.3^{\mathrm{c}}$ \\
\hline & $(6.4-7.7)$ & $(7.6-8.6)$ & $(265-620)$ & $(118-210)$ & $(54-83)$ & $(54-85)$ & $(3.7-5.7)$ & $(1.1-1.4)$ \\
\hline 240 & $\begin{array}{c}7.7^{\mathrm{b}} \\
(7.3-8.2)\end{array}$ & $\begin{array}{c}8.0^{\mathrm{a}} \\
(7.7-8.3)\end{array}$ & $\begin{array}{c}785^{a} \\
(344-1225)\end{array}$ & $\begin{array}{c}233^{c} \\
(157-309)\end{array}$ & $\begin{array}{c}123^{\mathrm{a}} \\
(73-174)\end{array}$ & $\begin{array}{c}76^{\mathrm{a}} \\
(54-97)\end{array}$ & $4.3^{\mathrm{a}, \mathrm{b}}$ & $1.9^{\mathrm{d}}$ \\
\hline
\end{tabular}

The contribution of recognizable phytoplankton cells to carbon flux was much greater at 40 and $80 \mathrm{~m}$ than in deeper water (data not shown). Phytoplankton flux at 40 and $80 \mathrm{~m}$ began to increase during the last week of April (sample E), with the greatest flux at $80 \mathrm{~m}$ in sample F. Excepting sample E at $80 \mathrm{~m}$, chains of Thalassiosira spp. accounted for more than $70 \%$ of phytoplankton biomass in the 40 and $80 \mathrm{~m}$ traps at the times of maximum chl a flux (Fig. 5, samples E to $G$ ). With the exception of sample $G$ at $240 \mathrm{~m}$, Thalassiosira spp. also accounted for more than $80 \%$ of the biomass of phytoplankton at 150 and $240 \mathrm{~m}$ at these times (samples F and G; Fig. 5). Sample G at $240 \mathrm{~m}$ was dominated by the autotrophic flagellate Chrysochromulina sp., which was also abundant in 80, 150, and $240 \mathrm{~m}$ traps in early April (sample A). Following the sinking of Thalassiosira spp. in the first half of May, the chain-forming diatoms Chaetoceros spp. were the most prominent of the recognizable cells in the 40, 80, and $150 \mathrm{~m}$ traps (samples I and J) in terms of biomass (Fig. 5). This is consistent with water column data, which indicated that Chaetoceros spp. did not regain their earlier predominance until late May, well after the storm. By the end of the time series, the sinking Chaetoceros cells had not yet reached the $240 \mathrm{~m}$ traps, which were still largely composed of Thalassiosira spp. Floc layer samples

Fig. 5. Relative contribution (by mass) of various phytoplankton species to the total recognizable phytoplankton biomass (by microscopy) vs. day of the year in traps at $40,80,150$, and $240 \mathrm{~m}$ depth. A to $\mathrm{J}$ are explained in the legend for Table 1
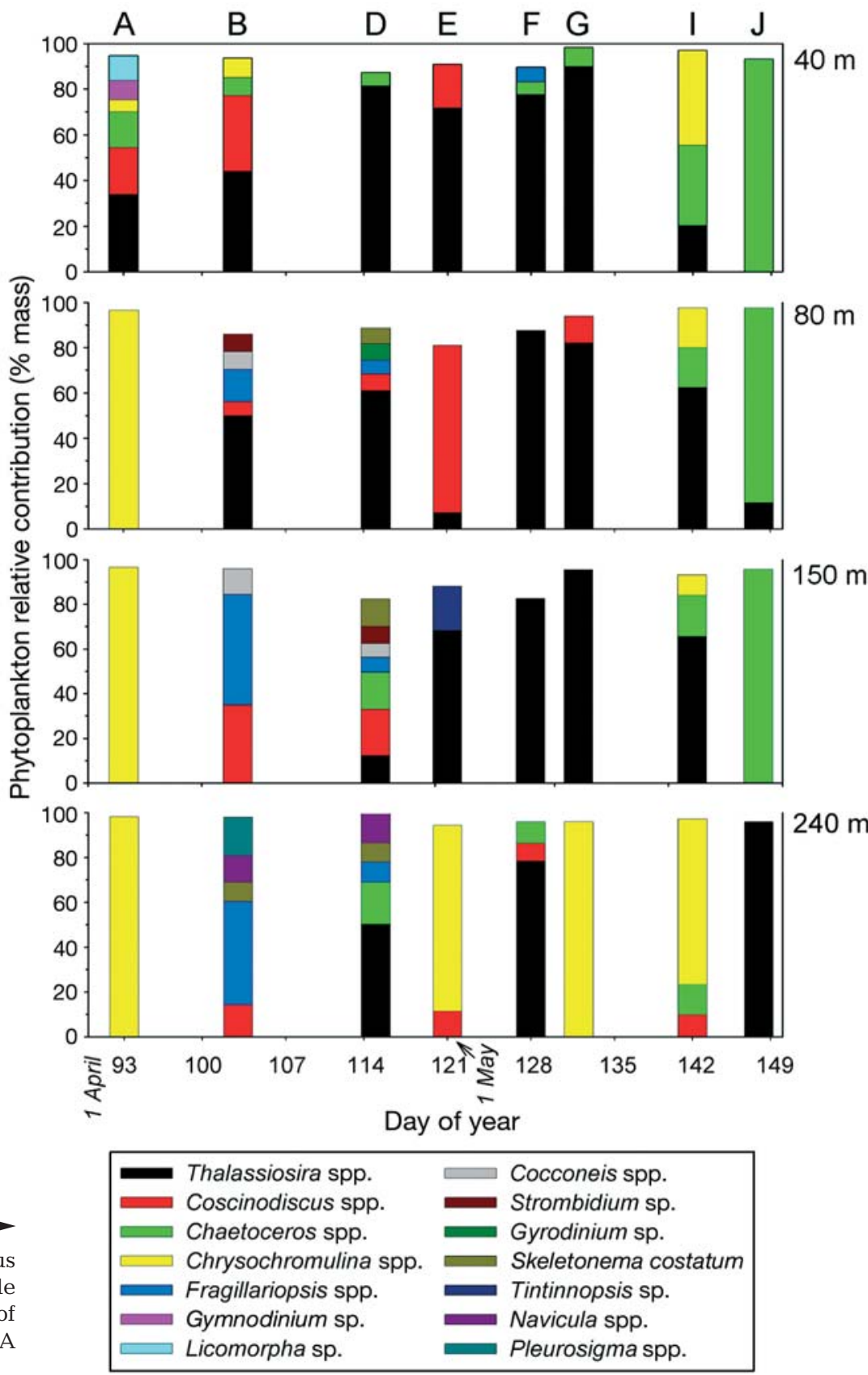
from the sediment surface were also examined, revealing only a few benthic, pennate diatoms in March, but auxospores of several Chaetoceros species were common by the middle of May at volume concentrations similar to those in the UML (i.e. $3 \times 10^{5} \mathrm{l}^{-1}$ ). After 5 July, there were no recognizable phytoplankton cells in the sediment floc layer.

Fecal pellets made the largest contribution to trap carbon content in mid-April and late May at 150 and $240 \mathrm{~m}$ depths (>90\%; Fig. 6). The relative contribution of fecal pellet carbon to total recognizable particle mass decreased in early May at all depths, comprising ca. $70 \%$ of total carbon content at 150 and $240 \mathrm{~m}$ but only $20 \%$ at 40 and $80 \mathrm{~m}$. This decrease in fecal pellet contribution to trap contents relative to diatom cells was not simply due to an increase in phytoplankton flux, but rather to a combination of increasing phytoplankton flux and decreasing pellet flux, as the volume concentration of feces decreased 10-fold during the peak of the sinking event at all trap depths. Fecal pellet contents were dominated by resting spores and vegetative cells of Chaetoceros spp., as well as other centric diatoms and a few pennate forms.

\section{Cumulative flux}

The temporal trends in carbon flux were similar at all depths, with cumulative flux for the $62 \mathrm{~d}$ trap deployment period ranging from $13.5 \mathrm{gC} \mathrm{m}^{-2}$ at $150 \mathrm{~m}$ to $16.5 \mathrm{~g} \mathrm{C} \mathrm{m}^{-2}$ at $80 \mathrm{~m}$ (Table 5). Presumably cumulative flux was greater at 80 than at $40 \mathrm{~m}$ because some of the phytoplankton production occurred below the $40 \mathrm{~m}$ trap, and was greater at 240 than at $150 \mathrm{~m}$ due to resuspension of organic material and/or defecation by verti-

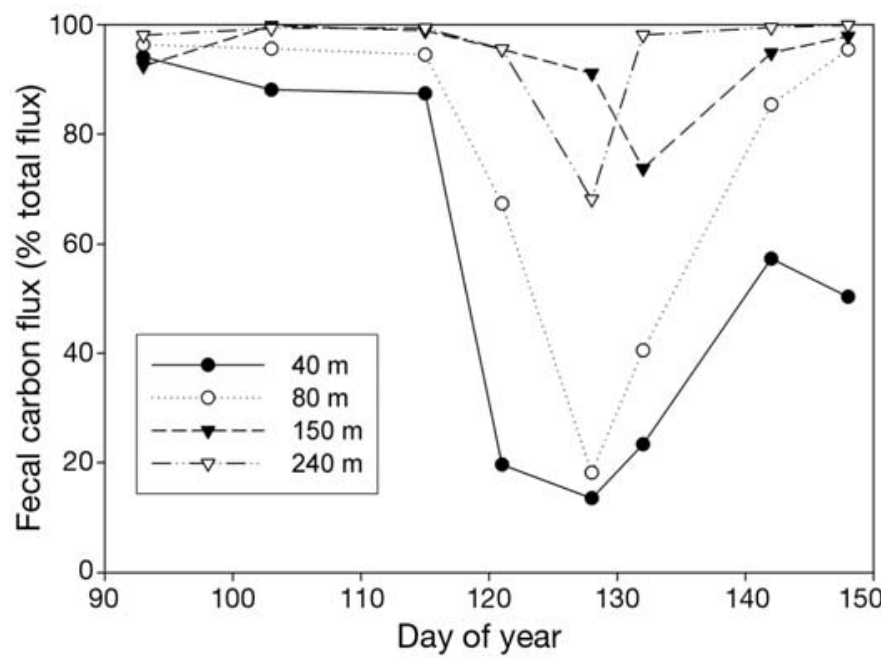

Fig. 6. Zooplankton fecal pellet flux at 40, 80, 150, and $240 \mathrm{~m}$ depths vs. day of the year as a relative proportion of total organic carbon flux at each depth
Table 5. Cumulative flux of organic carbon $\left(\mathrm{g} \mathrm{C} \mathrm{m}^{-2}\right)$ and total chloropigments $\left(\mathrm{g} \mathrm{m}^{-2}\right)$ determined by sediment traps from 29 March to 30 May (62 d) in Conception Bay, Newfoundland. For explanation of 'estimated' flux see Results

\begin{tabular}{|lccc|}
\hline $\begin{array}{l}\text { Trap } \\
\text { depth }(\mathrm{m})\end{array}$ & $\begin{array}{c}\text { POC } \\
\text { measured }\end{array}$ & $\begin{array}{c}\text { POC } \\
\text { (estimated) }\end{array}$ & $\begin{array}{c}\text { Total } \\
\text { chloropigments }\end{array}$ \\
\hline 40 & 15.9 & - & 0.26 \\
80 & 16.5 & - & 0.27 \\
150 & 13.5 & 20.0 & 0.20 \\
240 & 16.0 & 25.0 & 0.20 \\
\hline
\end{tabular}

cally migrating zooplankton below $150 \mathrm{~m}$. Cumulative Tchl flux was similar at 40 and $80 \mathrm{~m}$ (i.e. $0.26-0.27 \mathrm{~g}$ $\left.\mathrm{m}^{-2}\right)$ and at 150 and $240 \mathrm{~m}\left(0.20 \mathrm{~g} \mathrm{~m}^{-2}\right.$; Table 5). The trap deployment period did not encompass the entire POC sinking event at 150 and $240 \mathrm{~m}$ (Fig. 3). Assuming a similar temporal profile of the sinking event at 150 and $240 \mathrm{~m}$ as at $80 \mathrm{~m}$, we estimated the flux of POC over the entire event (ca. $79 \mathrm{~d}$ ) to be ca. $20 \mathrm{~g} \mathrm{C} \mathrm{m}^{-2}$ at $150 \mathrm{~m}$ and $25 \mathrm{~g} \mathrm{C} \mathrm{m}^{-2}$ at $240 \mathrm{~m}$, about $50 \%$ greater than the observed POC fluxes at these depths (Table 5).

\section{DISCUSSION}

\section{Vertical flux}

The spring bloom in Conception Bay begins during mid- to late March in response to increasing light intensity and photoperiod and decreasing wind stress (Stead \& Thompson 2003). During initiation of the bloom, the water column is isothermal and $<0^{\circ} \mathrm{C}$. Throughout the course of the bloom, temperatures at and below the SCM are always $\leq 0^{\circ} \mathrm{C}$ (our Fig. 2, Parrish et al. 2005). Thus, salinity primarily regulates vertical stability during the bloom period, as is typical of other boreal and sub-arctic coastal environments (Tamelander \& Heiskanen 2004). Maximum chl a concentrations of ca. $2.5 \mu \mathrm{g} \mathrm{l}^{-1}$ were observed during the first week of May. This relatively low value, probably attributable to a storm in early April, is about half the peak values recorded during spring blooms in Conception Bay in other years (Stead \& Thompson 2003).

Although spring phytoplankton production in Conception Bay begins during March, over $75 \%$ of the vertical flux of spring POC and phytoplankton pigments from the euphotic zone occurs in May (Stead \& Thompson 2003, this study). Vertical flux increases following nutrient depletion and subsequent cell senescence during early May, as indicated by elevated levels of chlorophyllide $a$ in sediment traps at 40 to $150 \mathrm{~m}$ (Redden 1994). A reduction in the daily POC and pigment flux to 40 and $80 \mathrm{~m}$ from mid- to late May signals the decline of 
the spring phytoplankton bloom (Figs. 3 \& 4). Bloom termination in Conception Bay is also marked by decreasing compound-specific fatty acid $\delta^{13} \mathrm{C}$ values in the seston (Ostrom et al. 1997), suggesting severe limitation of phytoplankton by dissolved inorganic carbon (Ramos et al. 2003), which decreases by $33 \%$ during the course of the bloom (Ostrom et al. 1997).

The mean and maximum fluxes of TPM, POC, PON, chl $a$, and phaeopigments in Conception Bay are high relative to values from most coastal studies around the world, including upwelling systems. Fluxes in Conception Bay are most similar to data from boreal and subarctic waters, and fall in the middle of the range observed by Colombo et al. (1996) at $150 \mathrm{~m}$ in the Gulf of St. Lawrence in May (TPM flux 5-9 $\mathrm{g} \mathrm{m}^{-2} \mathrm{~d}^{-1}$; POC flux 225-275 $\mathrm{mg} \mathrm{m}^{-2} \mathrm{~d}^{-1}$; PON flux $25 \mathrm{mg} \mathrm{m}^{-2} \mathrm{~d}^{-1}$ ). POC flux in Conception Bay is also similar to rates for Dabob Bay, Washington, USA (21-470 $\mathrm{mg} \mathrm{C} \mathrm{m}^{-2} \mathrm{~d}^{-1}$ at $60 \mathrm{~m}$, Downs \& Lorenzen 1985), the Peru Upwelling at $50 \mathrm{~m}$ depth (224-418 $\mathrm{mgC} \mathrm{m} \mathrm{m}^{-2} \mathrm{~d}^{-1}$, Wakeham et al. 1984), the Santa Barbara (California) channel in May following a spring bloom of Chaetoceros spp. (Passow et al. 2001), and at 4 stations in the Barents Sea (410-1090 mgC m $\mathrm{m}^{-2} \mathrm{~d}^{-1}$; Andreassen \& Wassmann 1998). Peak fluxes of chl a are similar in Conception Bay and the Barents Sea (3-10 and 2-13 $\mathrm{mg} \mathrm{m}^{-2} \mathrm{~d}^{-1}$, respectively), as are peak fluxes of phaeopigments (4-6 and 3-11 $\mathrm{mg} \mathrm{m}^{-2} \mathrm{~d}^{-1}$, respectively, Andreassen \& Wassmann, 1998). Maximum POC and chl a fluxes in Conception Bay are much lower than those observed by Olesen (1995) at a shallow (30 m) site in the Kattegat (ca. $1400 \mathrm{mg} \mathrm{C} \mathrm{m}^{-2} \mathrm{~d}^{-1}$ and $1100 \mathrm{mg} \mathrm{chl} \mathrm{a} \mathrm{m}^{-2} \mathrm{~d}^{-1}$ ), but are much greater than off the Antarctic peninsula

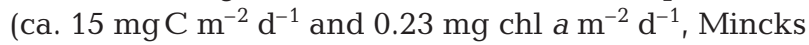
et al. 2005), in an Antarctic bay (60-120 $\mathrm{mg} \mathrm{C} \mathrm{m}^{-2} \mathrm{~d}^{-1}$, Baldwin \& Smith 2003), and in Storfjorden, Svalbard (ca. $90 \mathrm{mg} \mathrm{C} \mathrm{m}^{-2} \mathrm{~d}^{-1}$ in September, Glud et al. 1998).

The peak fluxes of POC and Tchl in Conception Bay, ca. 800 and $10 \mathrm{mg} \mathrm{m}^{-2} \mathrm{~d}^{-1}$ respectively, occur at $80 \mathrm{~m}$ depth in mid-May. This timing agrees with published data, which suggest that chloropigments begin to arrive at the sediment surface shortly after bloom initiation in late March, with peak flux values generally occurring in late May or June (Stead \& Thompson 2003). The peak POC flux at $80 \mathrm{~m}$ is about double that measured in Conception Bay by Parrish et al. (2005), while the peak chl a flux is about 4 -fold higher. During the primary sinking event, we observed a similar pattern of chl $a$ and phaeopigment concentration vs. depth as did Andreassen \& Wassmann (1998), i.e. chl $a>$ phaeopigments above 60 to $80 \mathrm{~m}$ depth and phaeopigments $>\mathrm{chl} a$ at depths $>80 \mathrm{~m}$. However, outside the primary sinking event in Conception Bay, phaeopigment concentrations exceeded chl a concentrations at all depths.

Estimated cumulative POC flux from the euphotic zone during the development and decline of the spring phytoplankton bloom in Conception Bay is highest at $240 \mathrm{~m}\left(25 \mathrm{~g} \mathrm{C} \mathrm{m}^{-2}\right)$ and lowest at $40 \mathrm{~m}\left(16 \mathrm{~g} \mathrm{C} \mathrm{m}^{-2}\right.$, Table 5). These values are greater than seasonal cumulative sedimentation in the northern Baltic Sea (5.3 $\mathrm{g} \mathrm{C} \mathrm{m}^{-2}$, Tamelander \& Heiskanen 2004). The POC flux at $240 \mathrm{~m}$ is equivalent to $56 \%$ of the estimated primary production of $45 \mathrm{~g} \mathrm{C} \mathrm{m}^{-2}$ during this 2 mo period (Table 6), and greater than the range of daily fluxes to $100 \mathrm{~m}$ in the northeastern Atlantic Ocean (10 to $40 \%$ of primary production, Turley et al. 1995).

Cumulative Tchl flux at $240 \mathrm{~m}$ during the sinking event was $0.20 \mathrm{~g} \mathrm{~m}^{-2}$ (Table 5). Given that $35 \%$ of Tchl is undegraded chl a (Table 3), this is equivalent to a cumulative, seasonal flux of chl $a$ of $70 \mathrm{mg} \mathrm{m}^{-2}$. Chl $a$ is mixed to at least $10 \mathrm{~cm}$ depth in the sediments at the bottom of Conception Bay (Redden 1994), perhaps as a result of the high densities of head-down, depositfeeding polychaetes (Scheibe 1991), which subduct chl a by burrow irrigation and 'hoeing' of surface sediments (Josefson et al. 2002). This bioturbation results in a uniform concentration of $\mathrm{chl} a$ in the upper $10 \mathrm{~cm}$

Table 6. Seasonal organic carbon budget ( $79 \mathrm{~d}$ period) for the formation and fate of the spring diatom bloom in Conception Bay, Newfoundland. \% PP watcol: percentage of the total primary production utilized in the water column; \% PP benthos: percentage of the total primary production utilized in the benthos; \% benthic flux: percentage of the estimated benthic flux at $240 \mathrm{~m}$ utilized in the benthos. For caveats, parameters and parameter values, see 'Materials and methods: First-order seasonal carbon budget'

\begin{tabular}{|c|c|c|c|c|}
\hline Process & $\mathrm{gC} \mathrm{m}^{-2}$ & $\%$ PP watcol & $\%$ PP benthos & $\%$ benthic flux \\
\hline Primary production & 45 & - & - & - \\
\hline Utilization by water column bacteria & 2.1 & 5 & - & - \\
\hline Utilization by water column mesozooplankton & 8.3 & 18 & - & - \\
\hline Estimated benthic flux at $240 \mathrm{~m}$ & 25 & 56 & - & - \\
\hline Anaerobic benthic utilization & 2 & - & 4 & 8 \\
\hline Aerobic benthic utilization & 19 & - & 42 & 77 \\
\hline Utilization by suprabenthic zooplankton & 1 & - & 2 & 4 \\
\hline Utilization by macrobenthos & 2.8 & - & 6 & 11 \\
\hline Net carbon deposition (by difference) & 0.2 & - & 0.4 & 0.8 \\
\hline
\end{tabular}


of sediments (Scheibe 1991, Redden 1994, Stead \& Thompson 2003), with an areal concentration of $200 \mathrm{mg}$ chl a m${ }^{-2}$ (Scheibe 1991). Thus, although the sinking spring bloom results in a large export of undegraded chl a from the UML to the benthos (i.e. $70 \mathrm{mg}$ $\mathrm{m}^{-2}$ ), this seasonal flux contributes only $35 \%$ to a much larger pool of sedimentary chl $a$. Since it arrives at the bottom during May (ca. 30 d, Fig. 4), this material represents a mass-specific rate of increase of chl $a$ in the sediments of ca. $0.01 \mathrm{~d}^{-1}$. Independently collected data for sediment chloropigment content (Redden 1994) shows a $44 \%$ increase in the concentration of chl a integrated over the upper $10 \mathrm{~cm}$ between April and May, fairly close to the $35 \%$ predicted from our flux measurements and the sedimentary chl a values of Scheibe (1991).

High remineralization rates of seasonal pulses of POC accompanied by very low turnover rates of sedimenting chl a have been reported frequently in the literature, most recently by Josefson et al. (2002) and Mincks et al. (2005). While some authors have attributed low rates of degradation of chl a to sub-zero water temperatures (Beaulieu 2002, Mincks et al. 2005), others have found low rates of degradation even at temperatures $>7^{\circ} \mathrm{C}$, leading to alternative hypotheses, including rapid burial of chl a by deposit feeders (Josefson et al. 2002) and the packaging of chl $a$ in diatom resting spores (Beaulieu 2002). We hypothesize that, although the benthos of Conception Bay is permanently cold, since chl $a$ is well-preserved in warmer sediments $\left(>7^{\circ} \mathrm{C}\right.$ ) elsewhere (Josefson et al. 2002) the low degradation rates of chl $a$ in Conception Bay are probably due to factors other than low temperature, such as burial by deposit feeders (Scheibe 1991) or the predominance of diatom resting spores (this study).

\section{Quality of sinking material}

Small, chain-forming centric diatoms, in particular Skeletonema costatum, Chaetoceros spp., and Thalassiosira spp., generally dominate the spring bloom in Conception Bay, indicating that the bloom is inoculated primarily from planktonic rather than benthic sources (McQuoid \& Godhe 2003). These taxa are similar to those that dominate the ice-edge spring bloom in the Barents Sea (Andreassen \& Wassmann 1998), in the Kattegat (Olesen 1995), and in the latter stages of arctic spring blooms generally (von Quillfeldt 1997). Dominant phytoplankton species in the sediment traps from Conception Bay are representative of these abundant spring bloom taxa, particularly Thalassiosira spp. and Chaetoceros spp., the latter occurring frequently in spring sediment trap material around the world (Beaulieu 2002). Sinking velocities during the mass flux of predominantly intact phytoplankton cells and diatom chains in Conception Bay in early May are 20 to $23 \mathrm{~m} \mathrm{~d}^{-1}$, averaged over all trap depths. These values are similar to those of Passow (1991), who recorded a mass flux of Chaetoceros spp. of 16 to $32 \mathrm{~m} \mathrm{~d}^{-1}$ during the senescent phase of a spring bloom in the Baltic Sea, and of Pilskaln et al. (1998), who observed sinking velocities of 16 to $25 \mathrm{~m} \mathrm{~d}^{-1}$ in Monterey Bay, California. The fecal pellet contribution to this flux in Conception Bay is low, similar to some spring blooms at higher latitudes but greater water temperatures (i.e. $5 \%$ of bloom C flux in the Kattegat, Olesen \& Lundsgaard 1995), but not to all such blooms (Andreassen \& Wassmann 1998). Our data do not enable us to account for the decrease in the absolute flux of zooplankton fecal pellets during the main phytodetritus sinking event, but possible explanations include a decrease in zooplankton abundance, inhibition of zooplankton grazing by phytoplankton alkaloids, and coprophagy by micro- and mesozooplankton. However, we can conclude that sinking of the spring phytoplankton bloom in Conception Bay occurs at rates commonly observed for nutrient-depleted diatoms. This conclusion is supported by microscopic examination of trap contents (Fig. 5) and by fatty acid analyses, which show the dominant fatty acid in sediment trap samples to be 16:1 167, typical of diatoms (Parrish et al. 2005). According to chloropigment profiles, relatively undegraded phytoplankton cells and chains account for $54 \%$ of Tchl flux to $80 \mathrm{~m}, 40 \%$ to $150 \mathrm{~m}$, and $33 \%$ to $240 \mathrm{~m}$. This means that $61 \%$ of the undegraded chl a that passes $80 \mathrm{~m}$ reaches $240 \mathrm{~m}$, which is comparable to the ratio of $67 \%$ for material passing from 80 to $220 \mathrm{~m}$ recorded by Parrish et al. (2005), also in Conception Bay, and compares with a transfer efficiency of ca. $50 \%$ for total lipids, neutral lipids, and polyunsaturated fatty acids (PUFAs; Parrish et al. 2005). The mean phaeopigment:chl a ratio was $<1.9$ at all depths during the sinking event (Table 4), defining the sinking material as 'fresh phytodetritus' (Beaulieu 2002). Furthermore, the mean $\mathrm{C}: \mathrm{N}$ ratios were relatively low (8-9) and independent of depth during the sinking event in May, in agreement with values from many other sites in the world ( $\mathrm{C}: \mathrm{N}=7-9$; Beaulieu 2002).

The patterns of POM, POC, PON, and Tchl flux were similar with both depth and duration of the bloom. POM was high during the bloom and represented 25 to $35 \%$ of TPM. These values are similar to those found in polls in western Norway, but much higher than those reported for Norwegian fjords (Wassmann 1991). Mean POC ranged from 8.8 to $12 \%$ of TPM at and above $150 \mathrm{~m}$, to $5.6 \%$ at $240 \mathrm{~m}$. This is higher than the organic matter proportions at $150 \mathrm{~m}$ depth in the Gulf of St. Lawrence (2.6-6.7\%, Colombo et al. 1996), but much lower than the value of $32 \%$ of TPM recorded in 
the central North Pacific Ocean at $378 \mathrm{~m}$ by Wakeham et al. (1984). Thus preservation of organic material during sinking seems to be greater in Conception Bay than at other coastal sites in the region but not as high as at some other sites globally.

Spring bloom phytoplankton in Conception Bay is rich in neutral (i.e. storage) lipids, particularly during the nutrient limitation phase from mid-bloom onwards, when lipids account for up to $6 \%$ of TPM (Parrish et al. 2005). These lipids are rich in PUFAs (40 to 55\% of total fatty acids), which are highly conserved during sinking, with PUFA proportions increasing from $\leq 20 \%$ before and immediately after the bloom to 30-35\% during maximum bloom deposition at $220 \mathrm{~m}$ (Parrish et al. 2005). These PUFA proportions may remain high for 4 to 6 wk during bloom deposition in April and May. The lipolysis and hydrolysis indices were low and did not differ among trap depths, suggesting low levels of utilization of the lipid in the sinking bloom material (Parrish et al. 2005).

\section{Fate of spring bloom production}

Bloom organic material can be utilized by both water column and benthic heterotrophs. However, in Conception Bay the predominant fate of spring primary production was benthic deposition, estimated to be $25 \mathrm{~g} \mathrm{C} \mathrm{m}^{-2}$, or ca. $56 \%$ of the seasonal primary production of $45 \mathrm{~g} \mathrm{C} \mathrm{m}^{-2}$ (Table 6). Kudo et al. (2007) recorded the same value $\left(25 \mathrm{~g} \mathrm{C} \mathrm{m}^{-2}\right)$ for export to the benthos in another sub-arctic coastal location, Funka Bay, Hokkaido, Japan, although this represented only $38 \%$ of spring primary production. Water column heterotrophs utilized $10.4 \mathrm{gC} \mathrm{m}^{-2}$, or $23 \%$ of total primary production in Conception Bay, with mesozooplankton using over 3 times more carbon than bacteria. Kudo et al. (2007) found that $34 \%$ of spring bloom production was decomposed in the deep layer of the water column in Funka Bay. Aerobic utilization by benthic microbes and meiofauna in Conception Bay accounted for ca. $77 \%$ of the $25 \mathrm{~g} \mathrm{C} \mathrm{m}^{-2}$ reaching the bottom, assuming a linear relationship between aerobic mineralization rate and deposition rate throughout the deposition event (Table 6). This agrees with the relatively high rates of benthic oxygen uptake in Conception Bay relative to temperate and tropical benthos (Glud et al. 1998) and with the rapid remineralization of pulses of organic carbon generally observed in the benthos (days to weeks; Beaulieu 2002), and is consistent with several studies demonstrating that aerobic psychrophilic bacteria in permanently cold $\left(-1.7^{\circ} \mathrm{C}\right)$ polar sediments exhibit a high metabolic rate (e.g. Arnosti et al. 1998, Thamdrup \& Fleischer 1998, Knoblauch et al. 1999). According to Thamdrup \& Fleischer (1998) thermal adaptation of psychrophiles in such sediments compensates for direct temperature effects on metabolism. In cold sediments receiving relatively high organic input, the microbial community appears to respond to the availability of organic matter rather than to temperature change (Kostka et al. 1999). In the Antarctic, sediment microorganisms are able to exploit pulses of organic material very rapidly, and metabolic transformation of organic matter occurs at rates similar to those observed in temperate regions (Fabiano \& Danovaro 1998).

In Conception Bay, utilization of carbon by anaerobic processes, benthopelagic zooplankton, and benthic macrofauna accounted for only ca. $23 \%$ of deposited carbon (Table 6). Our first-order budget accounts for over $99 \%$ of the estimated benthic flux of $25 \mathrm{~g} \mathrm{C} \mathrm{m}^{-2}$ during the sinking event, leaving ca. $0.2 \mathrm{~g} \mathrm{C} \mathrm{m}^{-2} \mathrm{~d}^{-1}$ for utilization later or for burial (Table 6). Since the rate of aerobic utilization of the bloom by the benthos is the largest term in the budget, a slight overestimation of this rate could have a large effect on the overall balance. Nevertheless, we conclude that the largest sink for spring bloom particulate primary production in Conception Bay is aerobic utilization by benthic micro- and meiofauna $(42 \%$ of total primary production), followed by water column mesozooplankton (18\%; Table 6).

Of the total primary production during spring, $21 \%$ is unaccounted for in our budget (Table 6). Three aspects of water column heterotrophy are poorly constrained. First, we have not estimated microzooplankton grazing. Although microzooplankton abundance was very low at the time of the main sinking event (C. H. McKenzie unpubl. data), some unpublished estimates of microzooplankton grazing in Conception Bay do account for much of the daily primary production during spring (S. Roy pers. comm.). Nevertheless, at present we conclude that microzooplankton grazing is a poorly known component of the carbon budget of Conception Bay. Secondly, the estimate of mesozooplankton biomass during spring, ca. $0.5 \mathrm{~g} \mathrm{C} \mathrm{m}^{-2}$ over the upper $50 \mathrm{~m}$ in early May (Tian et al. 2003), is an approximation. This value compares with a pre-bloom biomass of $1.5 \mathrm{~g} \mathrm{C} \mathrm{m}^{-2}$ in the Greenland Sea, which increases to $20 \mathrm{~g} \mathrm{C} \mathrm{m}^{-2}$ during the bloom (Noji et al. 1999), and of ca. $2 \mathrm{~g} \mathrm{C} \mathrm{m}^{-2}$ in the Gulf of Maine during the spring bloom (Townsend et al. 1994). The estimate of Tian et al. (2003) was based on daytime tows and was normalized to the upper $50 \mathrm{~m}$. Thus, our estimate did not take into account a potential deep source of mesozooplankton biomass. We would only need to double mesozooplankton biomass to $1 \mathrm{~g} \mathrm{C} \mathrm{m}^{-2}$, closer to the published values mentioned above and within the range reported by Tian et al. (2003) for Conception Bay, to account for the non-utilized carbon in our bud- 
get (Table 6). Finally, a growth efficiency of $33 \%$ for bacteria was used here to estimate total remineralization (Table 6), but bacterial growth efficiency can vary between 10 and $50 \%$ in Conception Bay (Pomeroy et al. 1991). Assuming a value of $10 \%$ would have resulted in an estimate of ca. $6 \mathrm{~g} \mathrm{C} \mathrm{m}^{-2} \mathrm{~d}^{-1}$ utilized by water column bacteria.

\section{Is the export exceptional in a global context?}

Because water column temperature is $<0^{\circ} \mathrm{C}$ during the production and sinking of the spring bloom in Conception Bay, one of our questions was whether the time course, duration, and amplitude of the bloom and its sinking component are exceptional compared with other temperate and boreal seas. Iverson et al. (2000) constructed some empirical regression equations that predict many of the relevant variables in a global context. We compared predictions from these equations to our data and previously published results from a simulation model of Conception Bay (Tian et al. 2003). The Iverson model is empirical, not mechanistic, and is based on relatively few field studies world-wide, mainly in tropical and temperate waters. Thus, our data provide an opportunity to test the applicability of the model to site-specific data from very cold water. In addition, this exercise helps to place our site-specific measurements in a larger, global context and to test predictions that sub-zero temperatures during the spring bloom lead to exceptionally high rates of vertical flux.

Petersen \& Curtis (1980) and Pomeroy et al. (1991) hypothesized that benthopelagic coupling is exceptionally efficient in sub-arctic and arctic waters due to suppression of water-column bacterial activity and a lagged response in zooplankton numbers. Based on the annual mean concentration of chl a $(0.41 \pm 0.39 \mu \mathrm{g}$ $\mathrm{I}^{-1}$; Stead \& Thompson 2003), Conception Bay falls into the High Variability (HV) province of Iverson et al. (2000). We therefore used the HV equations of Iverson et al. (2000) to predict annual integrated primary, new, and export production for Conception Bay. Substituting the value of $0.41 \mu \mathrm{g} \mathrm{l}^{-1}$ for annual mean chl a concentration into the $\mathrm{HV}$ regression equation yields $95 \%$ confidence limits (CLs) of 146 to $156 \mathrm{~g} \mathrm{C} \mathrm{m}^{-2} \mathrm{yr}^{-1}$ for primary production. Lacking year round primary production data, we compared this predicted range with the output value from the published model, which is $129 \mathrm{~g} \mathrm{C} \mathrm{m}^{-2} \mathrm{yr}^{-1}$ (Tian et al. 2003). Thus there is no evidence that Conception Bay is exceptionally productive in global terms. Substituting the annual estimate of primary production from Tian et al. (2003) into the Iverson et al. (2000) equation gives a predicted $95 \%$ CL range of 41 to $54 \mathrm{~g} \mathrm{C} \mathrm{m}^{-2}$ for annual export from the photic zone to the benthos, very close to the value of $43 \mathrm{gC}$ $\mathrm{m}^{-2}$ from the model (Tian et al. 2003). Thus the cold environment of Conception Bay does not result in a greater export of organic carbon to the benthos than is typical globally. Assuming that the spring bloom primary production estimate of Redden (1994) of $45 \mathrm{gC}$ $\mathrm{m}^{-2}$ is all new production, and that primary production during the remainder of the year is largely based on recycled nitrogen, the annual export predicted by the Tian et al. (2003) model of $43 \mathrm{gC} \mathrm{m}^{-2}$ is essentially equal to the annual new production. Thus, annual exported production and new primary production appear to be in balance in Conception Bay over an annual cycle.

In conclusion, a large proportion of the spring phytoplankton bloom in Conception Bay settles to the benthos as intact cells and chains. Most of the particulate material sedimenting to deep waters and to the benthos does so after nutrient depletion and subsequent cell senescence. This material is of high organic and lipid content, but may be nitrogen-poor due to inorganic nutrient limitation of the bloom. While the sinking flux is high, it is within the predicted $95 \%$ CLs of recent global models. Thus, while low temperature may regulate important qualitative properties of the sinking organic material, it does not result in remarkably high flux given the levels of new primary production in Conception Bay.

Acknowledgements. We thank M. Riehl and E. Hatfield for technical assistance and Drs. L. R. Pomeroy, W. J. Wiebe, and G. T. Rowe for their energetic collaboration and sharing of data and ideas. This work was made possible by personnel of the Field Services Unit at the Ocean Sciences Centre of Memorial University and was supported by an NSERC Strategic Grant to D.D. and R.J.T. and by NSERC Discovery Grants to R.J.T. and D.D.

\section{LITERATURE CITED}

Andreassen IJ, Wassmann P (1998) Vertical flux of phytoplankton and particulate biogenic matter in the marginal ice zone of the Barents Sea in May 1993. Mar Ecol Prog Ser 170:1-14

Arnosti C, Jørgensen BB, Sagemann J, Thamdrup B (1998) Temperature dependence of microbial degradation of organic matter in marine sediments: polysaccharide hydrolysis, oxygen consumption, and sulfate reduction. Mar Ecol Prog Ser 165:59-70

Baker ET, Milburn HB, Tennat DA (1988) Field assessment of sediment trap efficiency under varying flow conditions. J Mar Res 46:573-592

Baldwin RJ, Smith KL (2003) Temporal dynamics of particulate matter fluxes and sediment community response in Port Foster, Deception Island, Antarctica. Deep-Sea Res II 50:1707-1725

Bathmann UU, Noji TT, Peinert R (1987) Copepod fecal pellets: abundance, sedimentation and content at a permanent station in the Norwegian Sea in May/June 1986. Mar Ecol Prog Ser 38:45-51 
Beaulieu S (2002) Accumulation and fate of phytodetritus on the sea floor. Oceanogr Mar Biol Annu Rev 40:171-232

Bloesch J, Burns NM (1980) A critical review of sediment trap technique. Schweiz Z Hydrol 42:15-55

Booth BC (1993) Estimating cell concentration and biomass of autotrophic plankton. In: Kemp PF, Sherr BF, Sherr EB, Cole JJ (eds) Handbook of methods in aquatic microbial ecology, Lewis Publishers, Boca Raton, FL, p 199-206

Budge SM, Parrish CC (2003) Fatty acid determination in cold water marine samples. Lipids 38:781-791

$>$ Choe N, Deibel D (2000) Seasonal vertical distribution and population dynamics of the chaetognath Parasagitta elegans in the water column and hyperbenthic zone of Conception Bay, Newfoundland. Mar Biol 137:847-856

$>$ Colombo JC, Silverberg N, Gearing JN (1996) Biogeochemistry of organic matter in the Laurentian Trough. I. Composition and vertical fluxes of rapidly settling particles. Mar Chem 51:277-293

$>$ Dagg MJ, Whitledge TE, Iverson RL, Goering JJ (1982) The feeding, respiration, and excretion of zooplankton in the Bering Sea during a spring bloom. Deep-Sea Res 29:45-63

deYoung B, Sanderson B (1995) The circulation and hydrography of Conception Bay, Newfoundland. Atmos-Ocean 33:135-162

Downs JN, Lorenzen CJ (1985) Carbon:pheopigment ratios of zooplankton fecal pellets as an index of herbivorous feeding. Limnol Oceanogr 30:1024-1036

> Drazen JC, Baldwin RJ, Smith KL (1998) Sediment community response to a temporally varying food supply at an abyssal station in the NE Pacific. Deep-Sea Res II 45:893-913

Fabiano M, Danovaro R (1998) Enzymatic activity, bacterial distribution, and organic matter composition in sediments of the Ross Sea (Antarctica). Appl Environ Microbiol 64:3838-3845

Fabiano MA, Pusceddu A, Dell'Anno A, Armeni M and others (2001) Fluxes of phytopigments and labile organic matter to the deep ocean in the NE Atlantic Ocean. Prog Oceanogr 50: 89-104

$>$ Glud RN, Holby O, Hoffman F, Canfield DE (1998) Benthic mineralization and exchange in Arctic sediments (Svalbard, Norway). Mar Ecol Prog Ser 173:237-251

Grebmeier JM, McRoy CP (1989) Pelagic-benthic coupling on the shelf of the northern Bering and Chukchi Seas. III. Benthic food supply and carbon cycling. Mar Ecol Prog Ser 53:79-91

Hargrave BT, Burns NM (1979) Assessment of sediment trap collection efficiency. Limnol Oceanogr 24:1124-1136

- Heiskanen AS, Leppänen JM (1995) Estimation of export production in the coastal Baltic Sea: effect of resuspension and microbial decomposition on sedimentation measurements. Hydrobiologia 316:211-224

Hobson KA, Fisk A, Karnovsky N, Holst M, Gagnon JM, Fortier M (2002) A stable isotope $\left(\delta^{13} \mathrm{C}, \delta^{15} \mathrm{~N}\right)$ model for the North Water food web: implications for evaluating trophodynamics and the flow of energy and contaminants. DeepSea Res II 49:5131-5150

> Iverson RL, Esaias WE, Turpin K (2000) Ocean annual phytoplankton carbon and new production, and annual export production estimated with empirical equations and CZCS data. Glob Change Biol 6:57-72

> Josefson AB, Forbes TL, Rosenberg R (2002) Fate of phytodetritus in marine sediments: functional importance of macrofaunal community. Mar Ecol Prog Ser 230:71-85

$>$ Juul-Pedersen T, Nielsen TG, Michel C, Møller EF and others (2006) Sedimentation following the spring bloom in Disko
Bay, West Greenland, with special emphasis on the role of copepods. Mar Ecol Prog Ser 314:239-255

Knoblauch C, Jørgensen BB, Harder J (1999) Community size and metabolic rates of psychrophilic sulfate-reducing bacteria in Arctic marine sediments. Appl Environ Microbiol 65:4230-4233

Kostka JE, Thamdrup B, Glud RN, Canfield DE (1999) Rates and pathways of carbon oxidation in permanently cold Arctic sediments. Mar Ecol Prog Ser 180:7-21

Kudo I, Yoshimura T, Lee CW, Yanada M, Maita Y (2007) Nutrient regeneration at bottom after a massive spring bloom in a subarctic coastal environment, Funka Bay, Japan. J Oceanogr 63:791-801

McQuoid MR, Godhe A (2003) Influence of benthic vs. pelagic seeding on coastal diatom bloom development. J Phycol 39(s1):42

Mincks SL, Smith CR, DeMaster DJ (2005) Persistence of labile organic matter and microbial biomass in Antarctic shelf sediments: evidence of a sediment 'food bank'. Mar Ecol Prog Ser 300:3-19

Noji TT, Rey F, Miller LA, Børsheim KY, Urban-Rich J (1999) Fate of biogenic carbon in the upper $200 \mathrm{~m}$ of the central Greenland Sea. Deep-Sea Res II 46:1497-1509

Olesen M (1995) Comparison of the sedimentation of a diatom spring bloom and of a subsurface chlorophyll maximum. Mar Biol 121:541-547

Olesen M, Lundsgaard C (1995) Seasonal sedimentation of autochthonous material from the euphotic zone of a coastal system. Estuar Coast Shelf Sci 41:475-490

Ostrom NE, Macko SA, Deibel D, Thompson RJ (1997) Seasonal variation in the stable carbon and nitrogen isotope biogeochemistry of a coastal cold ocean environment. Geochim Cosmochim Acta 61:2929-2942

Parrish CC, Thompson RJ, Deibel D (2005) Lipid classes and fatty acids in plankton and settling matter during the spring bloom in a cold ocean coastal environment. Mar Ecol Prog Ser 286:57-68

Parsons TR (1988) Trophodynamic phasing in theoretical, experimental and natural pelagic ecosystems. J Oceanogr Soc Jpn 44:94-101

Passow U (1991) Species-specific sedimentation and sinking velocities of diatoms. Mar Biol 108:449-455

> Passow U, Shipe RF, Murray A, Pak DK, Brzezinski MA, Alldredge AL (2001) The origin of transparent exopolymer particles (TEP) and their role in the sedimentation of particulate matter. Cont Shelf Res 21:327-346

Peinert R, von Bodungen B, Smetacek VS (1989) Food web structure and loss rate. In: Bernhard S (ed) Productivity of the ocean: present and past. Wiley Interscience Publishers, Chichester, p 35-48

Petersen GH, Curtis MA (1980) Differences in energy flow through major components of subarctic, temperate and tropical marine shelf ecosystems. Dana 1:53-64

Pilskaln CH, Lehmann C, Paduan JB, Silver MW (1998) Spatial and temporal dynamics in marine aggregate abundance, sinking rate and flux: Monterey Bay, central California. Deep-Sea Res 45:1803-1837

Pomeroy LR, Wiebe WJ, Deibel D, Thompson RJ, Rowe GT, Pakulski JD (1991) Bacterial responses to temperature and substrate concentration during the Newfoundland spring bloom. Mar Ecol Prog Ser 75:143-159

Ramos CS, Parrish CC, Quibuyen TAO, Abrajano TA (2003) Molecular and carbon isotopic variations in lipids in rapidly settling particles during a spring phytoplankton bloom. Org Geochem 34:195-207

Redden AM (1994) Grazer-mediated chloropigment degradation and the vertical flux of spring bloom production in 
Conception Bay, Newfoundland. PhD thesis, Memorial University, St. John's

Redden AM, Thompson RJ, Deibel D (1993) Effects of shortand long-term freezing on chloropigments in cultured diatoms and bivalve digestive gland and faeces as determined by standard fluorometry and HPLC. Arch Hydrobiol 129:67-87

Richoux NB, Deibel D, Thompson RJ, Parrish CC (2004a) Seasonal changes in the lipids of Mysis mixta (Mysidacea) from the hyperbenthos of a cold-ocean environment (Conception Bay, Newfoundland). Can J Fish Aquat Sci 61:1940-1953

Richoux NB, Thompson RJ, Deibel D, Parrish CC (2004b) Seasonal and developmental variation in the lipids of Acanthostephia malmgreni (Amphipoda) from the hyperbenthos of a cold-ocean environment (Conception Bay, Newfoundland). J Mar Biol Assoc UK 84:1189-1197

Richoux NB, Deibel D, Thompson RJ (2004c) Population biology of hyperbenthic crustaceans in a cold water environment (Conception Bay, Newfoundland). I. Mysis mixta (Mysidacea). Mar Biol 144:881-894

Rysgaard S, Thamdrup B, Riisgard-Petersen N, Fossing H, Berg P, Christensen PB, Dalsgaard T (1998) Seasonal carbon and nutrient mineralization in a high-Arctic coastal marine sediment, Young Sound, Northeast Greenland. Mar Ecol Prog Ser 175:261-276

Scheibe S (1991) The benthic macrofauna of the deep sublittoral in Conception Bay (Newfoundland, Canada). MSc thesis, Christian Albrechts University, Kiel

Smetacek VS (1985a) Role of sinking in diatom life-history cycles: ecological, evolutionary and geological significance. Mar Biol 84:239-251

Smetacek VS (1985b) The annual cycle of Kiel Bight plankton: a long-term analysis. Estuaries 8:145-157

Stead RA, Thompson RJ (2003) The effect of the sinking spring diatom bloom on digestive processes of the coldwater protobranch Yoldia hyperborea. Limnol Oceanogr 48:157-167

Stead RA, Thompson RJ, Jaramillo JR (2003) Absorption efficiency, ingestion rate, gut passage time and scope for growth in suspension- and deposit-feeding Yoldia hyperborea. Mar Ecol Prog Ser 252:159-172

Editorial responsibility: Otto Kinne, Oldendorf/Luhe, Germany
Strathmann R (1967) Estimating the organic carbon content of phytoplankton from cell volume or plasma volume. Limnol Oceanogr 12:411-418

Strickland JDH, Parsons TR (1972) A practical manual of seawater analysis. Bull Fish Res Board Can 167

Tamelander T, Heiskanen AS (2004) Effects of spring bloom phytoplankton dynamics and hydrography on the composition of settling material in the coastal northern Baltic Sea. J Mar Syst 52:217-234

Thamdrup B, Fleischer S (1998) Temperature dependence of oxygen respiration, nitrogen mineralization and nitrification in Arctic sediments. Aquat Microb Ecol 15:191-199

Tian RC, Deibel D, Thompson RJ, Rivkin RB (2003) Modeling of climate forcing on a cold-ocean ecosystem, Conception Bay, Newfoundland. Mar Ecol Prog Ser 262:1-17

Townsend DW, Cammen LM (1988) Potential importance of the timing of spring plankton blooms to benthic-pelagic coupling and recruitment of juvenile demersal fishes. Biol Oceanogr 5:215-229

Townsend DW, Cammen LM, Holligan PM, Campbell DE, Pettigrew NR (1994) Causes and consequences of variability in the timing of spring phytoplankton blooms. DeepSea Res I 41:747-765

Turley CM, Lochte K, Lampitt RS (1995) Transformations of biogenic particles during sedimentation in the northeastern Atlantic. Philos Trans R Soc Lond B Biol Sci 348: 179-189

von Quillfeldt CH (1997) Distribution of diatoms in the Northeast Water Polynya, Greenland. J Mar Syst 10:211-240

Wakeham SG, Lee C, Farrington JW, Gagosian RB (1984) Biogeochemistry of particulate organic matter in the oceans: results from sediment trap experiments. Deep-Sea Res 31:509-528

Wassmann P (1991) Dynamics of primary production and sedimentation in shallow fjords and polls of western Norway. Oceanogr Mar Biol Annu Rev 29:87-154

Wassmann P, Bauerfeind E, Fortier M, Fukuchi M and others (2004) Particulate organic carbon flux to the Arctic Ocean sea floor. In: Stein R, Macdonald RW (eds) The organic carbon cycle in the Arctic Ocean. Springer, Berlin, p 101-138

Submitted: June 8, 2006; Accepted: October 15, 2007 Proofs received from author(s): March 20, 2008 